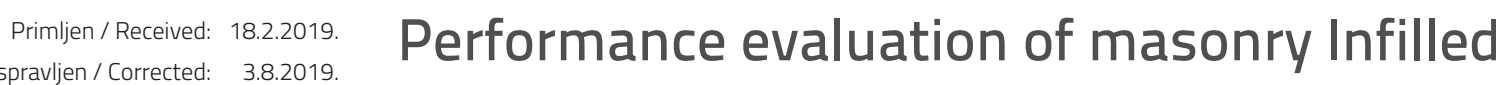 Prihuáen / Accepted: 3.12.2019. RC frame structures under lateral loads
}

Dostupno online / Available online: 10.4.2021.

Authors:

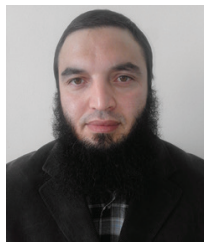

Mebarek Khelfi, PhD. CE

National Earthquake Engineering Research Centre, CGS, Algeria

Department of Civil Engineering, Faculty of Technology

Saad Dahlab University

mkhelfi@cgs-dz.org

Corresponding author

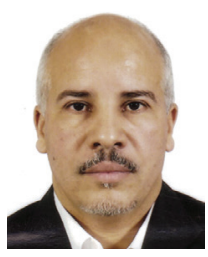

Prof. Nouredine Bourahla, PhD. CE National polytechnic school, Algeria nedbourahla@gmail.com

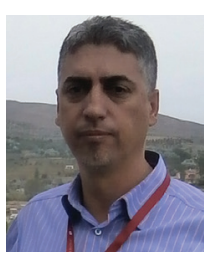

Assoc.Prof. Mustapha Remki, PhD. CE National Earthquake Engineering Research Centre, Algeria

mremki@cgs-dz.org
Mebarek Khelfi, Nouredine Bourahla, Mustapha Remki

Research Paper

\section{Performance evaluation of masonry Infilled RC frame structures under lateral loads}

Numerous studies on masonry infill panels have greatly contributed to the research of strength, stiffness and energy dissipation capacity of various buildings. If the effects of masonry panels are disregarded, structural damage will occur under any significant ground motion, and even lead to collapse of the entire structure. The mode of failure is strongly dependent on the masonry and RC frame interaction. This work proposes an evaluation method for determining the participation ratio of masonry infill panels on $\mathrm{RC}$ frames under lateral loads.

Key words:

indices of performance, lateral strength, lateral stiffness, dissipated energy, infill panels, RC frames, tapered joints

Prethodno priopćenje

Mebarek Khelfi, Nouredine Bourahla, Mustapha Remki

Ocjenjivanje učinkovitosti okvirnih AB konstrukcija sa zidanom ispunom pod utjecajem bočnih opterećenja

Brojne studije o zidanim ispunskim panelima uvelike su doprinijele razvoju istraživanja nosivosti, krutosti i sposobnosti disipacije energije raznih građevina. Zanemarivanje utjecaja zidanih ispuna može uzrokovati oštećenosti konstrukcije u slučaju značajnijih pomaka tla, pa čak i do rušenja čitave građevine. Način sloma uvelike ovisi o međusobnom djelovanju zidane ispune i AB okvira. $U$ ovom se radu predlaže metoda za ocjenjivanje koeficijenta učinkovitosti zidane ispune na $A B$ okvirne konstrukcije pod utjecajem bočnih opterećenja.

Ključne riječi:

koeficijenti učinkovitosti, bočna nosivost, bočna krutost, disipacija energije, zidane ispune, AB okviri, spojevi s vutom

Vorherige Mitteilung

Mebarek Khelfi, Nouredine Bourahla, Mustapha Remki

Bewertung der Effizienz von Rahmenstahlbetonkonstruktionen mit der Wandfüllung/mit der gemauerten Füllung, unter dem Einfluss von Seitenbelastungen

Die zahlreichen Studien über die gemauerten Füllungspanelle haben zum größten Teil der Entwicklung der Tragfähigkeit, Steifigkeit und Fähigkeit der Energiezerstreuung von verschiedenen Gebäuden beigetragen. Die Vernachlässigung des Einflusses von Wandfüllungen kann die Beschädigung der Konstruktion im Fall der bedeutenderen Verschiebung des Bodens verursachen und sogar zum Abbruch des gesamten Gebäudes führen. Die Art und Weise des Bruchs hängt zum großen Teil von der gegenseitigen Wirkung der Wandfüllung und des Stahlbetonrahmens ab. In dieser Arbeit wird die Methode für die Bewertung der Koeffizienten der Wirksamkeit der Wandfüllung für die Stahlbetonkonstruktionen unter dem Einfluss von Seitenbelastungen vorgeschlagen.

Schlüsselwörter:

Koeffizienten der Wirksamkeit, Seitentragfähigkeit, Seitensteifigkeit, Energiezerstreuung, Wandfüllungen, Stahlbetonrahmen, Verbindungen mit Wolle 


\section{Introduction}

Reinforced concrete structures with masonry infill are widely used for construction of buildings all over the world. Among several techniques for construction of low-rise buildings, this typology has been widely used because of its rapidity, simplicity, and low cost of building. Therefore, the understanding of the behaviour of this type of structure seems to be very important, particularly under seismic loads. Several published experimental tests [1-8] and numerical investigations [9-13] have proved that the presence of masonry panel in the reinforced concrete frames strongly increases the strength, the lateral stiffness, and the dissipative energy capacity of structures but it could negatively affect the overall behaviour of weak frames. An increase in research studies observed over the last two decades reflects the great attention devoted to understanding the interaction between masonry and the surrounding RC frames [14]. Currently, some seismic codes [15] suggest taking into account the presence of panel infill namely in calculating stiffness of structures.

Numerical models of MIFS (Masonry Infilled RC Frame Structures) can be classified in two categories: micro models and macro models. Micro models can very accurately predict real degradation of MIFS components. The smeared crack approach [45] and the discrete element method [46], are the most popular methods used and implemented in some refined codes of the finite element method, such as Ansys, Abaqus, Atena, etc. The recourse to such models presents a rigor variant because of their higher computation demand and higher sensitivity of nonlinear behaviour of materials. For such reasons, their application is not suitable in practical cases, namely on structures with large dimensions. Consequently, designers often use the second category of numerical models, which involves macro models. Macro models constitute a better choice for engineering purposes, as they enable prediction of global behaviour of MIFS with acceptable accuracy.

One of the important aims in the studies of MIFS is the improvement of its seismic performance. The performance of the MIFS can be expressed by qualitative or quantitative methods. The qualitative approach is based on the description of failure, on the geometry of the concrete boundary frame and on mechanical properties of materials, the aim being to predict possible failure modes of MIFS under seismic loads [1619]. The quantitative approach is mostly based on numerical techniques in which seismic performance is estimated through several parameters such as the ultimate strength, ductility, lateral stiffness, etc. Despite an important number of proposed analytical models, no consensus on a single unified approach for safe design of MIFS has so far been reached. This paradox of MIFS models is a consequence of the uncertainty in understanding interaction of masonry infills and RC frame elements [44]. When choosing adequate model for MIFS, other questions are still disturbing designers: how to choose an optimum MIFS concept (dimensions of masonry panels, dimensions of RC frame elements, or dimensions of openings and their location), which can provide good performance under lateral solicitations? To answer, many studies of series of MIFS specimens with different configurations have so far been made $[21,41,42]$. In [41], the shear capacity of each MIFS is expressed by computing internal forces in masonry infills and making comparison with the corresponding RC bare element, in order to investigate the influence of size and position of openings.

In this work, a new methodology is proposed in order to evaluate performance of the masonry fully infilled frame structures (MIFS) based on the calculation of the indices of performance IP. The indices of performance of the MIFS reflect the participation ratio of the infill panel compared to the overall MIFS behaviour in terms of selected parameters such as strength, lateral stiffness and energy dissipation. The first application presents a typical example for calculating the IP of MIFS in which numerical simulations of both MIFS and the corresponding RC bare frame are calibrated with experimental tests available in the literature. In addition, a second application of this proposed method on two infilled frames with different frame's configurations is implemented in order to compare their performance indices. In this part of the work, we are trying to highlight a non-famous design of the MIFS which deserves to be highlighted and in which the bounding frames are provided with fobs at beam's ends. The proposed method is also a useful tool for evaluating damage in the infill masonry panel under seismic loads, as well as a basic tool for the verification with seismic codes.

\section{Performance of masonry infilled frame}

When subjected to lateral loads, the infill panel extenuates the dominant effect in the behaviour of the MIFS, and many experimental tests indicate that its contribution may reaches 70 $\%$ of the MIFS strength $[3,20,21]$. The variation of the masonry infill effect on the MIFS behaviour depends on how the infill is used in the surrounding frames. Hence, it is appropriate to use several parameters for estimating contribution of the masonry infill to the overall behaviour of the MIFS. In the same way, some experimental and numerical studies were performed on MIFS specimens, with various dimensions of openings, to evaluate their performances. In such researches, the bare frame system and fully infilled RC frames were taken as references specimens $[41,42]$. The proposed methodology is based on the evaluation of the infilled panel effect in the frame structure by calculating their indices of performance (IP). The calculation of the IP is based on the fact that the overall effect of the MIFS at a displacement $\delta$ is obtained by the superposition effect of both the infill panel and the surrounding RC frame at the same displacement $\delta$. The evaluation of the MIFS performance is calculated as the ratio between the infill panel effect and the overall behaviour of the MIFS. This assumption is applicable if the masonry panel can be replaced by a diagonal strut when subjected to lateral loads (cf. Figure 1). 


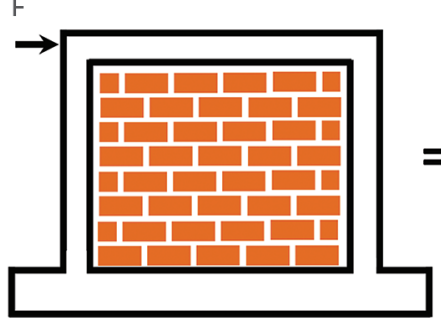

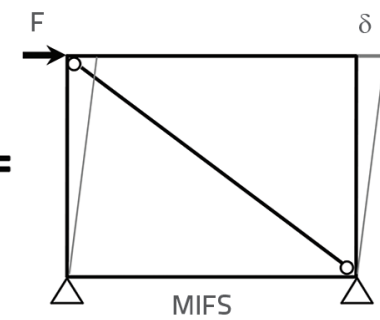

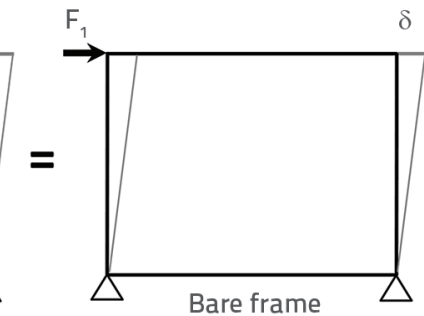

$\mathrm{F}=\mathrm{F}_{1}+\mathrm{F}_{2}$

Figure 1. Principle of superposition of effect of infill panel and bare frame structure

The equivalent diagonal strut is one of the most famous and practical model used for simulating of framed masonry panels. Inspired by Palyakov's works [22], Holmes was the first one who proposed the modelling of masonry infill by a simple diagonal strut [23]; and afterwards many authors have adopted the same idea [1, 9, 23-27]. The diagonal strut method is developed using different forms. It still offers results which are in good agreement with experimental tests, which proves its efficiency and justifies its implementation in some software dedicated to research and engineering applications $[11,20,27-33]$. Currently, the diagonal strut method is adopted in some seismic codes such as the Federal Emergency Management Agency, and Applied Technology Council [34, 35]. The proposed method of indices of performance is not applicable when the MIFS presents an early failure. This latter can be observed in masonry panel (by corner crushing of panel, dislocation of masonry units, out of plane failure, etc.) or in frame elements (by shear failure of beam-column joints due to lack of transverse reinforcement or bad quality of concrete, bar anchorage connection due to the slip of longitudinal bars of column in tension, etc.). Also, the method of IP cannot be used when perfect horizontal sliding failure of masonry panel occurs. In this latter failure, plastic hinges are formed at span length and not at the ends of RC members.

The indices of performance that have to be calculated with the proposed method are: the index of performance in terms of strength $\left(\mathrm{IP}_{\text {Strength }}\right)$, in terms of lateral stiffness $\left(\mathrm{IP}_{\text {Stiffness }}\right)$ and in terms of dissipated energy (IP $\left.\mathrm{D}_{\mathrm{D} \text {-Energy }}\right)$.

\subsection{Index of performance in terms of strength IP Strength}

In order to calculate the IP $\mathrm{P}_{\text {Strength }}$ of the MIFS, several steps have to be considered: In the first step we calculate and plot the curves capacity of both the MIFS system and its corresponding bare frame system (without infill). At each displacement $\delta$ of these curves we can determine the couple $\left(\mathrm{F}_{\text {MIFS }}(\delta)\right.$, $\left.\mathrm{F}_{\text {Bare Frame }}(\delta)\right)$. where : $F_{\text {MIFS }}(\delta), F_{\text {Bare Frame }}(\delta)$ are the response forces of the MIFS and the frame bare systems, respectively, cf. Figure 2 .

Based on the superposition principle cited above, the contribution of the masonry panel $\mathrm{F}_{\text {Masonry }}$ in terms of strength at the displacement $\delta$ is given by:

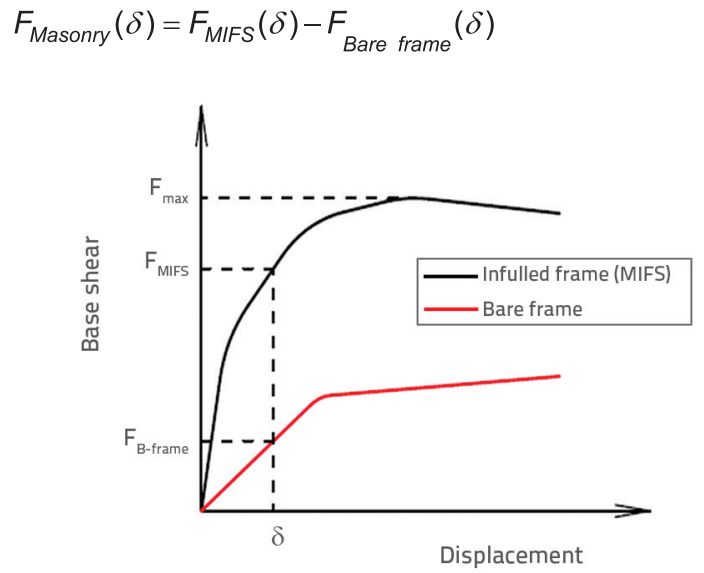

Figure 2. Parameters for evaluation of IP strength

The index of performance of the MIFS in terms of strength $\left(\mathrm{P}_{\text {Strength }}\right)$ is defined as

$I P_{\text {Strength }}=\frac{F_{\text {Masonry }}(\delta)}{F_{\text {Max }}}$

where: $F_{\max }$ is the maximum strength of the MIFS.

This index gives the ratio of the participation of the masonry panel in the MIFS in terms of strength at the displacement $\delta$. Additionally, the higher the value of this index, the better the masonry panel performs in the bounding area. The $\mathrm{IP}_{\text {strength }}$ can be calculated for each displacement $\delta$ of the curve capacity and we obtain the variation of the $\mathrm{IP}_{\text {Strength }}$ versus displacement at the top. The variation of the $\mathrm{IP}_{\text {strength }}$ as a function of displacement expresses the strength degradation of the infill panel during the progressive controlled displacement loading of the MIFS.

\subsection{Index of performance in terms of stiffness $\left(\mathrm{IP}_{\text {Stiffness }}\right)$}

The second important parameter that reflects performance of the masonry panel is the stiffness. Usually in the non-linear range, this parameter is evaluated using the secant stiffness $\mathrm{K}_{0}$ of the MIFS (cf. Figure 3). 


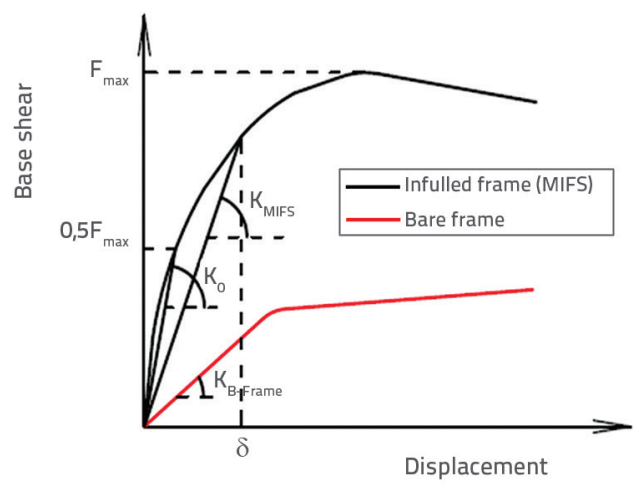

Figure 3. Parameters for evaluation of IP stiffness

The index of performance of the MIFS in terms of stiffness $\mathrm{IP}_{\text {Stiffness }}$ is calculated using the same analogy as in the $\mathrm{IP}_{\text {Strength. }}$. When subjected to seismic loads, the MIFS behaves as a monolithic element at small deformation levels (before separation of the infill). The system is considered as a fixedended wall and the initial stiffness of one-storey, one-bay infilled frame panel, is calculated by taking into account both shear and flexural deformations of the equivalent crosssectional area of the panel. At this first stage, the stiffness of the MIFS is given by:

$K_{\text {MIFS }}=\left(\frac{h_{\text {frame }}}{12 E I_{e}}+\frac{\kappa h}{G A_{e}}\right)^{-1}$

where:

$\mathrm{h}$ - the height of the frame and the infill

$E, G$ - the modulus of elasticity and the shear modulus of masonry

$\mathrm{I}_{e^{\prime}} A_{e}$ - the equivalent moment of elasticity and the equivalent area of the composite horizontal cross section of the MIFS

$\kappa \quad$ - is the shear coefficient $(1,20$ for rectangular crosssection)

At the second stage (after separation of the infill), the panel infill acts in the structure as a diagonal compression strut. Hence, the stiffness of the MIFS is calculated as a frame with diagonal braced strut. The failure mechanism of the infill represents the principal parameter which determines the width of the diagonal strut. In this case, the stiffness of the MIFS can be calculated as the sum of the frame stiffness and the pinned diagonal strut [38]. For calculation of $\mathrm{PP}_{\text {Stiffness' }}$ it is not representative to take the stiffness of the MIFS before the separation of the infill panel as initial stiffness for calculation [25]. The Eurocode 8 used simplified expressions for the evaluation of the initial elastic stiffness which depends on the elastic stiffness of the bare frame structure and the mechanical characteristics of the masonry [39]. In this work, the initial stiffness $K_{0}$ used for the calculation of $\mathrm{IP}_{\text {Stiffness }}$ is given by the slope of the line connecting the origin and $50 \%$ of maximum resistance of the MIFS [21] (cf.
Figure 3). The stiffness of the masonry panel is calculated using the following expression:

$K_{\text {Masonry }}(\delta)=K_{\text {MIFS }}(\delta)-K_{\text {Bare frame }}(\delta)$

The index of performance of the MIFS in terms of stiffness $\mathrm{IP}_{\text {Stiffness }}$ is defined as:

$I P_{\text {Stiffness }}(\delta)=\frac{K_{\text {Masonry }}(\delta)}{K_{0}}$

The $I P_{\text {Stiffness }}$ reflects the panel degradation level at the displacement ( $\delta$ ). A high value of $\mathrm{IP}_{\text {stiffness }}$ indicates an important contribution of the infill to the rigidify of the MIFS, which reduces the inter-story displacement but increases the seismic action on the structure. So, the judgment of a good performance of MIFS in terms of stiffness cannot be done independently from dynamic characteristics of the seismic load.

\subsection{Index of performance in terms of dissipated energy ( $\left.I P_{D-\text {-Energy }}\right)$}

The masonry infilled RC frame structure is characterized by a short elastic response. The most important quantity of seismic input energy is absorbed by the infill panel in the post-elastic domain, and this principally through cracking or crushing of the masonry panel and friction between the frame and bricks interfaces. The evaluation of dissipated energy of a structure is obtained from cyclic or dynamic tests, cf. Figure 4. The dissipated energy of the MIFS in each cycle represents the area surrounded by hysteretic curves, cf. Figure 5. The cumulative dissipated energy is also a useful parameter that indicates the degradation of the MIFS. In the case of the imposed displacement test, this parameter does not indicate real degradation of the structure.

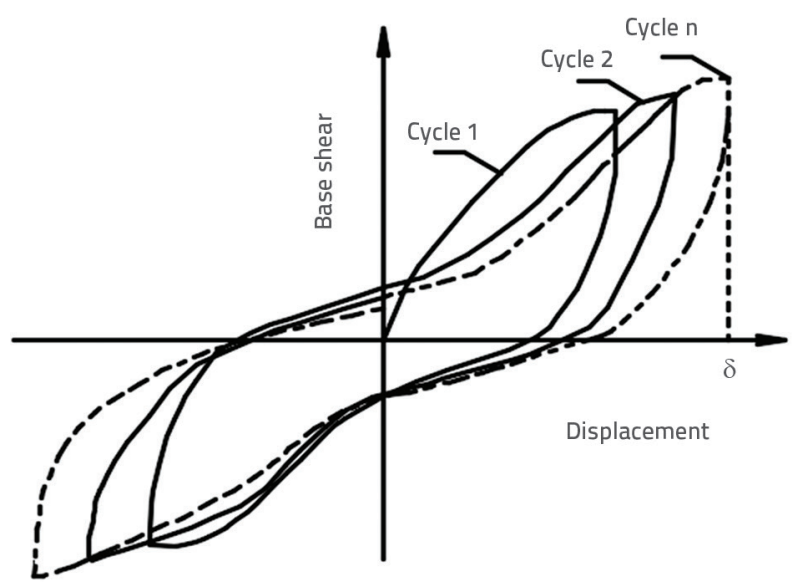

Figure 4. Typical curve of MIFS cyclic test

For a representative indication of degradation of a structure, we propose that the dissipated energy of each cycle be divided by the total displacement [38] (cf. Figure 5). 


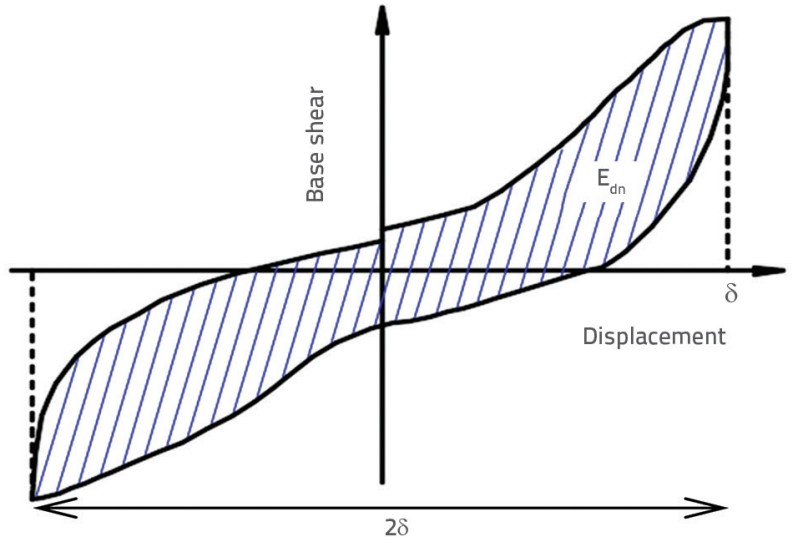

Figure 5. Parameters for evaluation of IP D-Energy

The corrected cumulative dissipated energy of the MIFS and the corresponding bare frame are respectively given by (6):

$\bar{E}_{d(M I F S)}\left(\delta_{i}\right)=\sum_{i=1}^{n} \frac{E_{d i}(\text { MIFS })}{2 \delta_{i}}$

So, the index of MIFS performance in terms of dissipated energy $\mathrm{IP}_{\mathrm{D} \text {-Energy }}$ is calculated as:

$\bar{E}_{d(\text { Bare frame })}\left(\delta_{i}\right)=\sum_{i=1}^{n} \frac{E_{d i(\text { Bare frame })}}{2 \delta_{i}}$

$I P_{D-\text { Energy }}\left(\delta_{i}\right)=\frac{\bar{E}_{d(\text { MIFS })}\left(\delta_{i}\right)-\bar{E}_{d(\text { Bare frame) }}\left(\delta_{i}\right)}{\bar{E}_{d(\text { MIFS })}\left(\delta_{i}\right)}$

The $I P_{D-E n e r g y}$ is considered as a complementary indicator of the infill performance. $A$ high value of the $\mathrm{IP}_{\mathrm{D} \text {-Energy }}$ indicates an important level of damage to the infill panel. The residual part of energy is transferred to the RC bounding frames. Since considered as a secondary structural element, the masonry infill can be repaired or replaced with new panels contrary to the RC frames which require difficult repair solutions.

\section{Numerical application}

In this section, the suggested method will be employed to evaluate and compare the performance of MIFS system. Results of experimental tests reported in the literature have been used for this purpose. The experimental tests under consideration are:

- A research program carried out by the Construction Engineering Research Laboratories (USA) designed to study the seismic vulnerability of MIFS [43].

- An experimental program performed by the laboratory of civil engineering of the University of Canterbury which constitutes a part of PHD thesis [20].

\subsection{Simulation of experimental test for evaluating Indices of performance}

The aim of the first numerical application is to validate the numerical model by calibration with experimental results, and present a typical example for the calculation of IP of MIFS. Static nonlinear tests are performed. The results obtained by testing half scale single bay -single story specimens are considered. The specimens correspond to model No (1) (bare frame specimen without infill) and model No (2) (with Concrete Masonry Unreinforced -CMU- panel) of the experimental program [43]. Geometrical characteristics and layout of reinforcement of the specimen are shown in Figure 6. The experimental data considered are summarized in tables 1, 2, and 3.

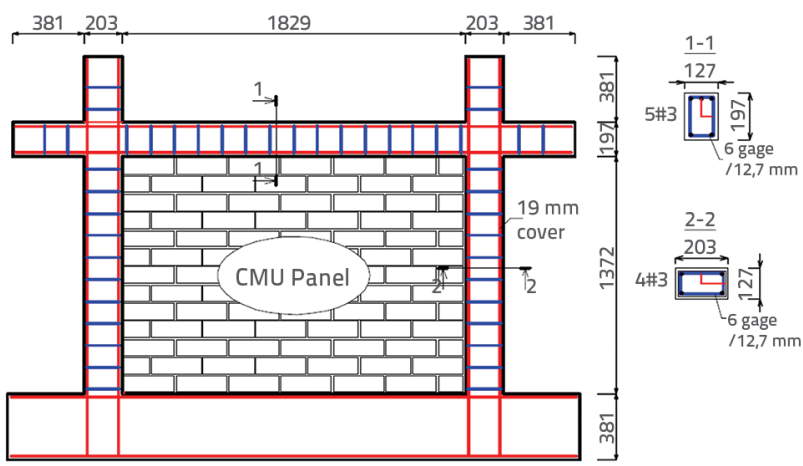

Figure 6. Geometry and reinforcement layout from reference [43]

Table 1. Mechanical characteristics of masonry

\begin{tabular}{|c|c|}
\hline $\begin{array}{c}\text { Compressive strength } \mathbf{f}^{\prime}{ }_{\mathbf{m}} \\
{[\mathrm{MPa}]}\end{array}$ & $\begin{array}{c}\text { Shear strength } \mathbf{f}^{\prime}{ }_{\mathrm{v}} \\
{[\mathrm{MPa}]}\end{array}$ \\
\hline 18.154 & 1.551 \\
\hline
\end{tabular}

Table 2. Mechanical characteristics of concrete

\begin{tabular}{|c|c|}
\hline $\begin{array}{c}\text { Compressive strength } \mathbf{f}_{\mathbf{m}} \\
{[\mathrm{MPa}]}\end{array}$ & $\begin{array}{c}\text { Elastic modulus } \mathbf{E}_{\mathbf{m}} \\
{[\mathrm{GPa}]}\end{array}$ \\
\hline 38.438 & 29.992 \\
\hline
\end{tabular}

Specimens are subjected to in-plane monotonic loading. A lateral bracing is provided for the elimination of out-of-plane movement. In order to evaluate the variation of the IP of specimens, numerical models are made based on calibration with experimental results. The numerical results are obtained using the finite element program SeismoStruct 2016 [40]. Columns and beams elements are modelled as non-linear

Table 3. Mechanical characteristics of reinforcing steel

\begin{tabular}{|c|c|c|c|c|}
\hline $\begin{array}{c}\text { Yield strength fy } \\
{[\mathrm{MPa}]}\end{array}$ & $\begin{array}{c}\text { Elastic modulus } \mathrm{E}_{\mathrm{m}} \\
{[\mathrm{GPa}]}\end{array}$ & $\begin{array}{c}\text { Yield strain } \\
\varepsilon_{\mathrm{y}}\end{array}$ & $\begin{array}{c}\text { Ultimate strength } \mathbf{f}_{\mathrm{su}} \\
{[\mathrm{MPa}]}\end{array}$ & $\begin{array}{c}\text { Ultimate strain } \\
\varepsilon_{\mathrm{su}}\end{array}$ \\
\hline 341.3 & 200 & 0.0017 & 544.7 & 0.10 \\
\hline
\end{tabular}


frame elements, and their cross sections are discretised into fibres. This method allows automatic calculation of mechanical properties of elements with an acceptable accuracy. The number of fibres of each section is arbitrarily chosen. The designer can start by a number of fibres equal to $A$ /As where: $A$ is the cross section of RC element and As is the area of a reinforcing steel bar. The final number of fibres is fixed by iterations and calibration with experimental results. The masonry infill panel is implemented in the program by means of a macro model element. This latter consists of two parallel struts and a shear spring in each direction [8], cf. Figure 7.

\section{Horizontal action}

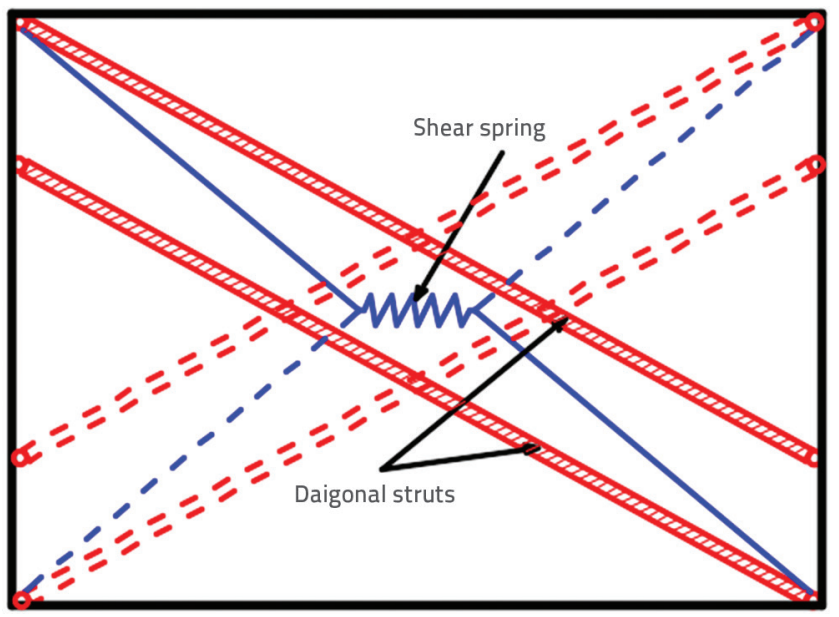

Figure 7. Details of macro model used to represent the masonry infill panel

A perfect elasto-plastic rule is adopted for the shear spring behaviour. The elastic stiffness $K_{s}$ of the shear spring is defined by the following expression:

$K_{s}=\gamma_{s} \frac{A_{m} E_{m}}{d_{m}} \cos ^{2} \theta$

where: $A_{m}$ and $d_{m}$ are the area of the equivalent diagonal strut, and diagonal length of the panel, respectively, $E_{m}$ is the elastic

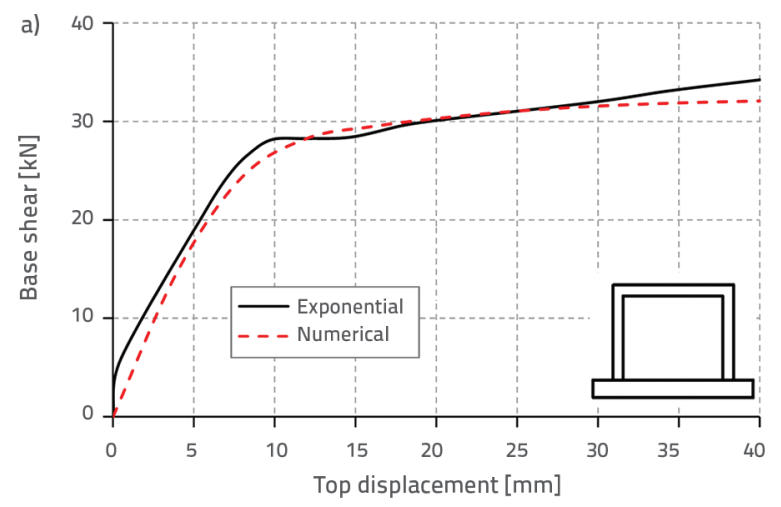

modulus of the masonry, $\theta$ is the angle of diagonal strut and $\gamma_{\mathrm{s}}$ is the coefficient of shear contribution in the total stiffness of the masonry panel [8]. The area of the equivalent diagonal is considered as a variable function with the axial displacement of the strut. The initial value of $A_{m}$ is calculated as follows:

$A_{0}=t b_{w}$

where: $t$ is the thickness of masonry panel and $b_{w}$ is the width of the equivalent diagonal strut evaluated using the Mainstone expression [26].

The shear strength is represented by the Mohr-Coulomb criterion in which the compression stress is calculated automatically from diagonal strut elements. The shear strength characteristics are evaluated using the Mann and Muller theory [40]. The modified initial bond limit strength and the coefficient of friction amount to $0.42 \mathrm{MPa}$ and 0.30 , respectively. The shear strength is limited by $\tau_{\mathrm{m}}$ which is calculated as follows:

$\tau_{m}=\frac{f^{\prime}{ }_{t b}}{2.3} \sqrt{1+\frac{f_{n}}{f^{\prime}{ }_{t b}}}$

where: $f_{\mathrm{n}}$ is the normal stress applied on brick masonry, and $f_{\mathrm{tb}}$ is the tensile strength of the brick masonry [40].

The elastic axial stiffness of struts $k_{a}$ is obtained using the following expression

$K_{a}=\frac{\left(\gamma_{s}-1\right) A_{m} E_{m}}{2 d_{m}}$

The axial stress is limited by the masonry compressive strength calculated with $\theta=36.87^{\circ}$, which represents the diagonal angle of the masonry panel. The compressive strength is considered equal to $\mathrm{f}_{\mathrm{m} \theta}^{\prime}=2.00 \mathrm{MPa}$. The remaining essential parameters of the numerical model of the masonry panel are:

- Ultimate strain, $\varepsilon_{\mathrm{u}}=0.03$.

- Strut area reduction strain, $\varepsilon_{1}=0.0005$.

- Residual strut area strain, $\varepsilon_{2}=0.01$.

- Proportion of stiffness assigned to shear, $50 \%$.

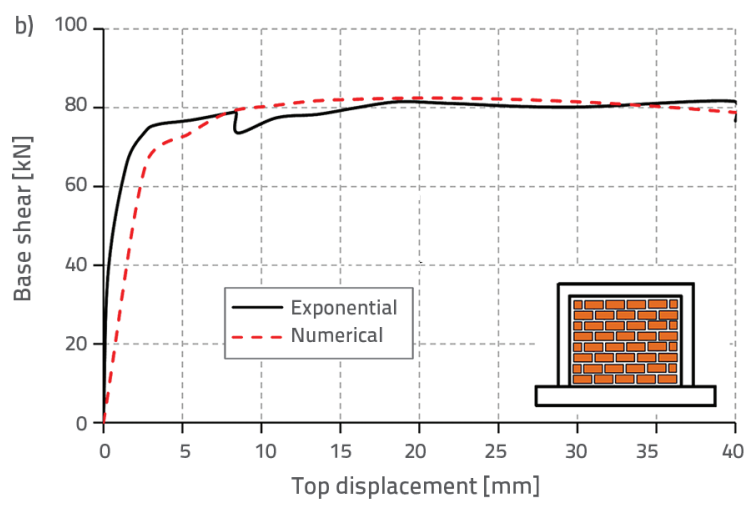

Figure 8. Comparison of experimental and numerical results: a) bare frame; b) MIFS 
Static nonlinear analyses are implemented. Comparisons between experimental and numerical results are reported in Figure 8. The curves presented in this figure indicate the variation of base shear versus top displacement of each specimen.

The numerical results indicated above are clearly in good agreement with experimental ones namely in terms of the capacity parameter. In the case of the MIFS, a slight difference is observed at top displacement levels down to $2.00 \mathrm{~mm}$ (corresponds of a drift of $0.15 \%$ ). After this displacement level, the numerical and experimental curves are practically close to each other. Based on the superposition assumption, the base shear participation of the masonry infill can be calculated at each displacement level using formula (1). The base shear participation of the MIFS components is presented in Figure 9.

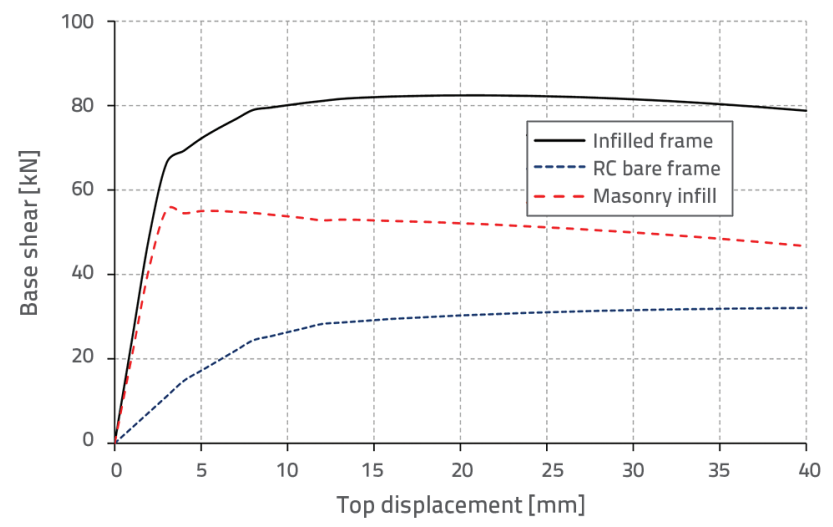

Figure 9. Variation of participation in terms of strength of the MIFS components

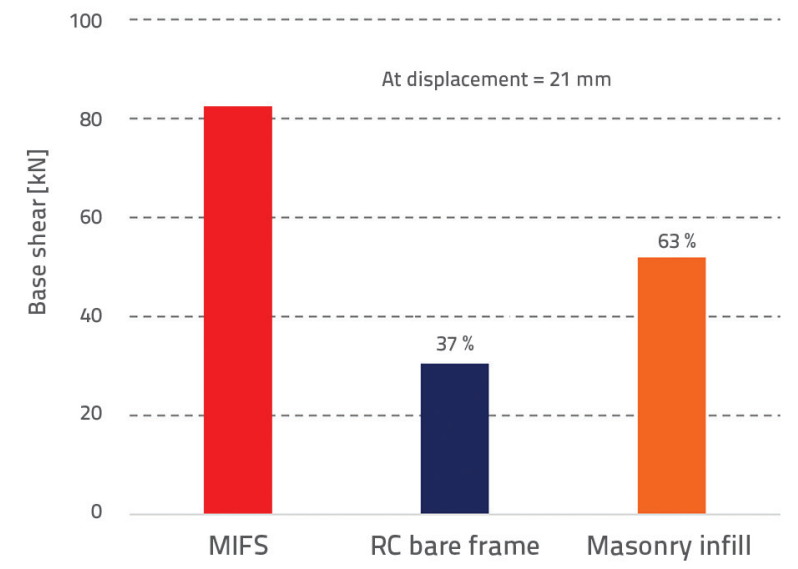

Figure 10. Ratio participation of MIFS components at maximum strength of MIFS

Figure 10 shows that the masonry infill has a considerable participation which exceeds $63 \%$ of the MIFS strength at 21.00 $\mathrm{mm}$ of top displacement level. This confirms the necessity of taking in consideration the masonry infill panel as a structural element in the seismic evaluation of MIFS. Using the formula expressed in (2), a graphical presentation of the $\mathrm{IP}_{\text {Strength }}$ variation as a function of top displacement is shown in Figure 11.

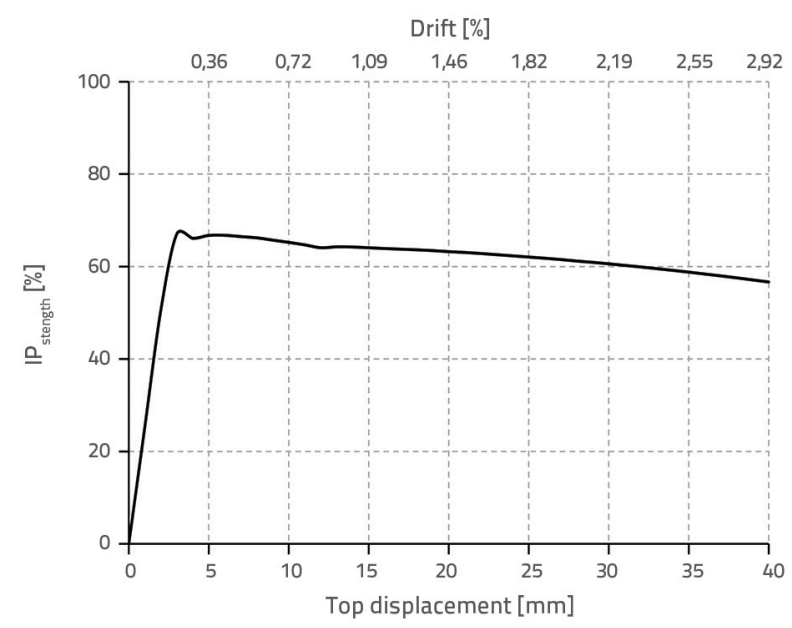

Figure 11. Variation of $\mathrm{IP}_{\text {strength }}$ of MIFS

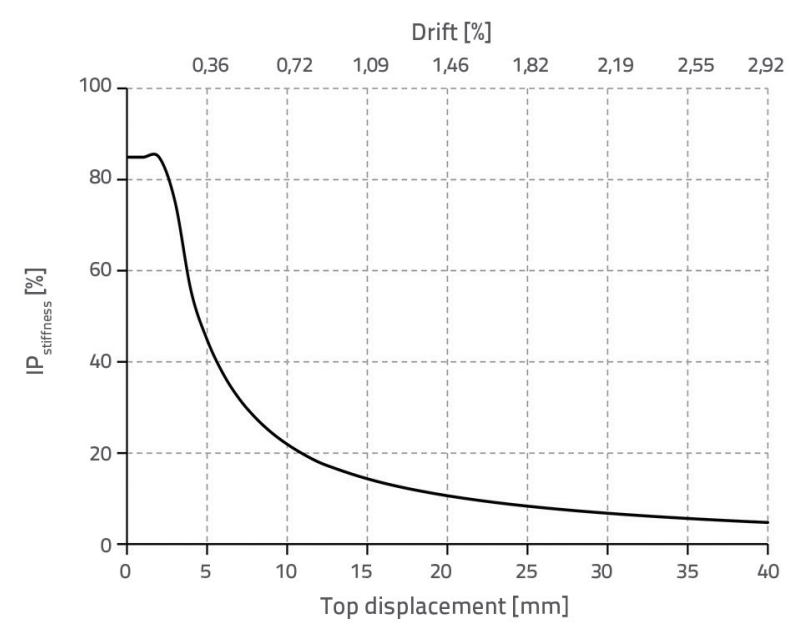

Figure 12. Variation of $I_{P_{\text {tiffness }}}$ of MIFS

Results presented in Figure 11 show that the $\mathrm{IP}_{\text {Strength }}$ of the MIFS increases at very short displacements levels, and that it reaches its maximum value (about $67 \%$ ) at $3.00 \mathrm{~mm}$ of the top displacement level. This displacement corresponds to the drift of $0.22 \%$, which practically represents the upper limit of slight damage state, and the beginning of the moderate damage state. Notting proves that the limit of each damage states of MIFS can be expressed by its corresponding drift interval [44]. On the other hand, $\mathrm{IP}_{\text {Stiffness }}$ remains constant (about $85 \%$ ) at slight damage state, which explicates the formation of the diagonal masonry strut without significant cracks in the infill (cf. Figure 12). After $3.00 \mathrm{~mm}$ of top displacement, the $I_{\text {Stiffness }}$ decreases dramatically compared to $\mathrm{IP}_{\text {Strength' }}$ which continues to decrease gradually until the end of the test. An important point which deserves to be noted is that after $3.00 \mathrm{~mm}$ of top displacement (drift of $0.22 \%$ ), and in spite of slight decrease in $\mathrm{IP}_{\text {Strength' }^{\prime}}$ the curve capacity of the MIFS continues to increase until $20 \mathrm{~mm}$ 
of top displacement (drift of $1.46 \%$ ). Between $0.22 \%$ and 1.46 $\%$ of drift, the excess of internal stress applied on the infill is transferred to the surrounding RC frames. Figure (13) shows the occurrence of visible diagonal cracks in masonry panel with no visible cracks in frame elements. At a drift of $1.46 \%$, numerical results show a start of decrease in the MIFS shear capacity. This agrees well with experimental results (cf. Figure 14) which point to the occurrence of cracks in the RC column element.

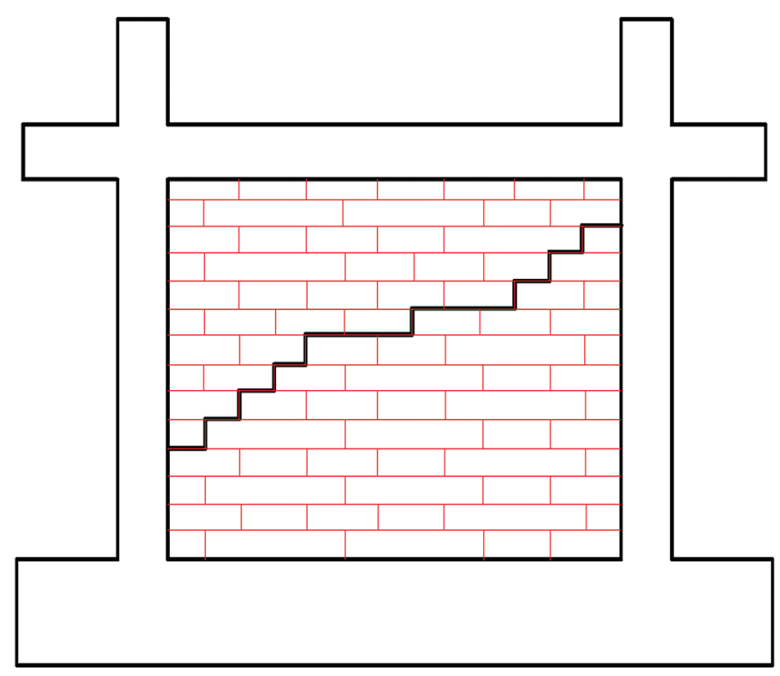

Figure 13. Crack survey of MIFS (Drift $=0.73 \%$ )

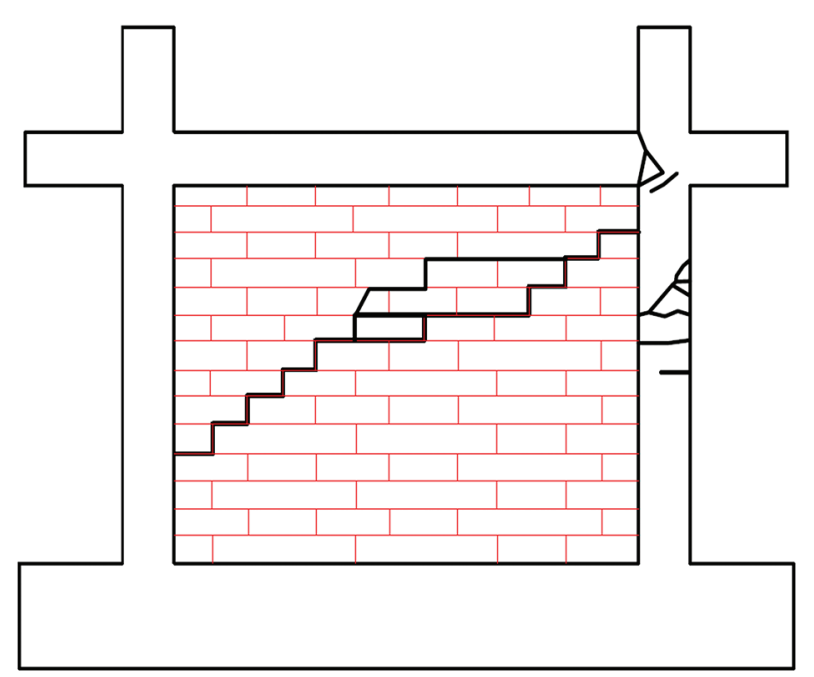

Figure 14. Crack survey of MIFS (Drift $=1.38 \%$ )

\subsection{Indices of performance of MIFS with tapered joints}

This part is devoted to the investigation of the behaviour of MIFS with tapered joints using the indices of performance. For this, two specimens of 3:4 scales and with different designs are considered. In this experimental campaign, both of the two tested units are fully infilled. The first unit represents a ductile structure with the one-bay single-story RC infilled frames. Geometrical characteristics and the corresponding reinforcement layout of Unit 1 are shown in Figure 15. Overall dimensions of Unit 2 are identical to those of Unit 1 but with different reinforcing detail (cf. Figure 16).

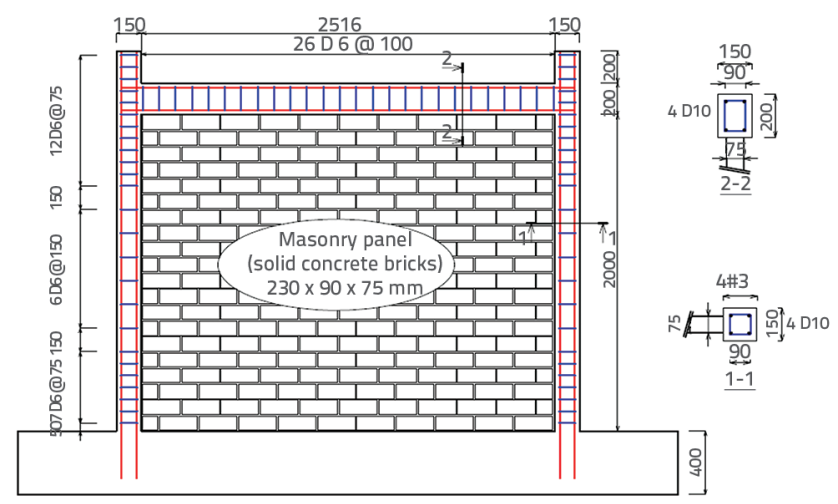

Figure 15. Geometry and reinforcement layout of Unit 1 (Simple MIFS)

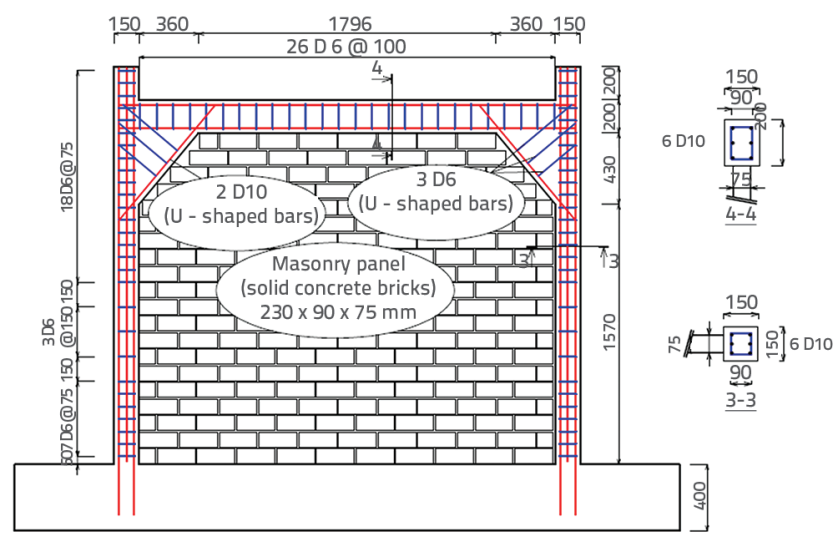

Figure 16. Geometry and reinforcement layout of Unit 2 (MIFS with tapered joints)

The Unit 2 is designed with tapered beam-column joints. The inclination of the beam ends of Unit 2 is selected to be perpendicular to the diagonal of the masonry panel [20]. Masonry panels of both specimens are not designed to resist gravity loads, which are directly transferred to the columns. For its simulation, a vertical constant load of $20 \mathrm{KN}$ is applied at the top of each column of the specimens. Laterally, quasi static loads are applied on each specimen in order to define their strength and degradation of their stiffness.

Figure 17 shows the controlled displacement-loading test applied to Unit 1 and Unit 2 with maximum storey drift of $1.5 \%$ and $2.0 \%$, respectively. Tables 4,5 , and 6 recapitulate the material characteristics of the specimens obtained from laboratory testing [20]. 

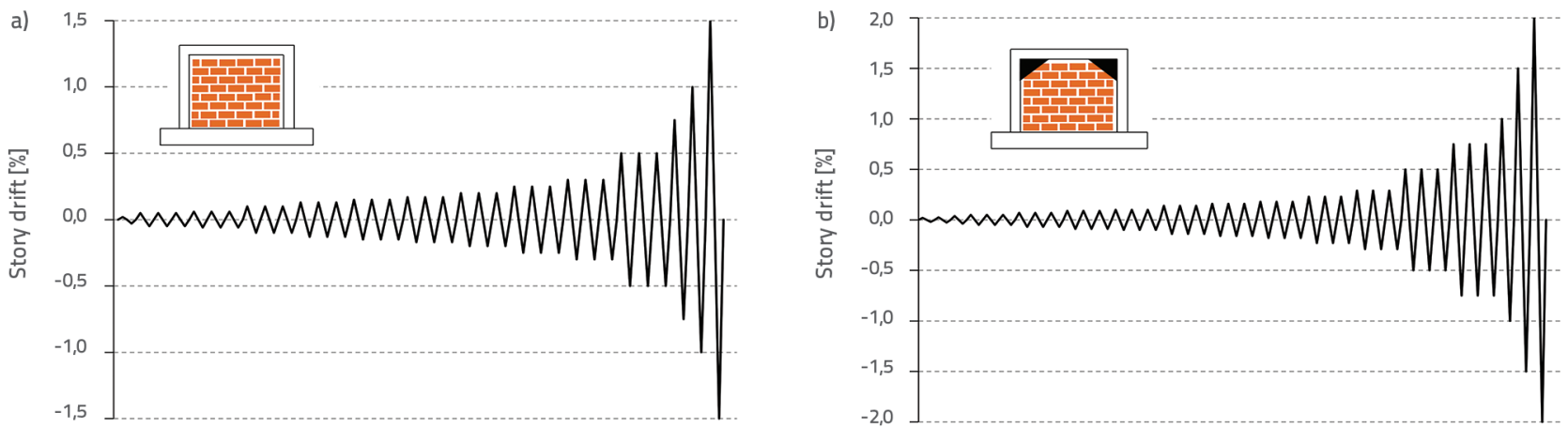

Figure 17. Typical cyclic lateral displacement applied on specimens: a) Unit 1, b) Unit 2

Table 4. Mechanical characteristics of masonry

\begin{tabular}{|c|c|c|c|}
\hline $\begin{array}{c}\text { Compressive strength } \mathbf{f}_{\mathrm{m}} \\
{[\mathrm{MPa}]}\end{array}$ & $\begin{array}{l}\text { Elastic modulus } \mathrm{E}_{\mathrm{m}} \\
{[\mathrm{MPa}]}\end{array}$ & $\begin{array}{c}\text { Initial bond strength } \tau_{0} \\
{[\mathrm{MPa}]}\end{array}$ & Coefficient of friction $\mu$ \\
\hline 19.30 & 11550 & 0.41 & 0.7 \\
\hline
\end{tabular}

Table 5. Mechanical characteristics of concrete

\begin{tabular}{|c|c|c|c|c|}
\hline Elements & Parametars & Compressive strength $\mathbf{f}_{\mathbf{m}}{ }[\mathrm{MPa}]$ & Tensile strengthf' ${ }_{\mathbf{t}}[\mathrm{MPa}]$ & ${\text { Elastic modulus } \mathrm{E}_{\mathbf{m}}[\mathrm{GPa}]}$ \\
\hline Unit 1 & 22.5 & 2.4 & 22.1 \\
\hline Unit 2 & 31.2 & 2.9 & 25.2 \\
\hline
\end{tabular}

Table 6. Mechanical characteristics of reinforcing steel

\begin{tabular}{|c|c|c|c|c|c|}
\hline $\begin{array}{c}\text { Parametars } \\
\text { Reinforcement } \\
\text { bar }\end{array}$ & $\begin{array}{c}\text { Yield strength } \mathbf{f}_{\mathrm{y}} \\
{[\mathrm{MPa}]}\end{array}$ & $\begin{array}{c}\text { Elastic modulus } \mathbf{E}_{\mathrm{m}} \\
{[\mathrm{GPa}]}\end{array}$ & $\begin{array}{c}\text { Yield strain } \\
\varepsilon_{\mathrm{y}}\end{array}$ & $\begin{array}{c}\text { Ultimate strength } \mathbf{f}_{\text {su }} \\
{[\mathrm{MPa}]}\end{array}$ & $\begin{array}{c}\text { Ultimate srain } \\
\varepsilon_{\text {su }}\end{array}$ \\
\hline$\Phi 6 \mathrm{~mm}$ & 353 & 207.6 & 0.0017 & 466 & 0.151 \\
\hline$\Phi 10 \mathrm{~mm}$ & 323 & 201.9 & 0.0016 & 441 & 0.253 \\
\hline
\end{tabular}

Table 7. Geometric characteristics of tapered joint parts

\begin{tabular}{|c|c|c|c|c|}
\hline Tapered Characteristics & $E A[k N]$ & El (os-2) $\left[\mathrm{kN} / \mathrm{m}^{2}\right]$ & $\mathrm{El}(\mathrm{os}-2)\left[\mathrm{kN} / \mathrm{m}^{2}\right]$ & GJ $\left[\mathrm{kN} / \mathrm{m}^{2}\right]$ \\
\hline Part 1 & $1.83 \cdot 10^{6}$ & $1.47 \cdot 10^{6}$ & $1.12 \cdot 10^{6}$ & $7.68 \cdot 10^{5}$ \\
\hline Part 2 & $3.30 \cdot 10^{4}$ & $1.73 \cdot 10^{4}$ & $7.59 \cdot 10^{3}$ & $2.43 \cdot 10^{3}$ \\
\hline Part 3 & $3.43 \cdot 10^{3}$ & $2.77 \cdot 10^{3}$ & $2.10 \cdot 10^{3}$ & $1.44 \cdot 10^{3}$ \\
\hline Part 4 & $4.54 \cdot 10^{3}$ & $3 . .44 \cdot 10^{3}$ & $2.34 \cdot 10^{3}$ & $1.25 \cdot 10^{3}$ \\
\hline
\end{tabular}

The numerical simulation is executed by SeismoStruct 2016 program [40]. In the model of Unit 2, the tapered joint is modelled as a succession of simple short bare elements with different geometric characteristics as illustrated in Figure 18. The geometric characteristics of each portion of the tapered joint are shown in Table 4.

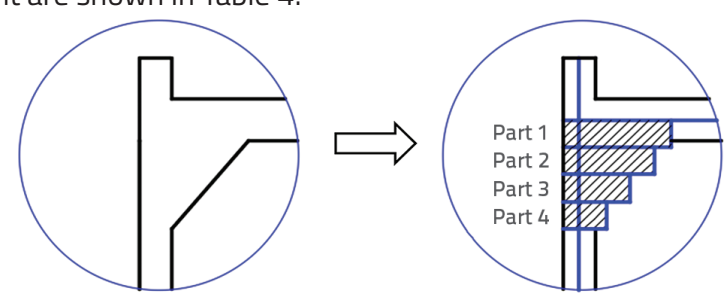

Figure 18. Simple discretization of tapered beam-column joint
A more detailed description of numerical model is reported in Section 3.2. The compressive strength is taken to be equal to $\mathrm{f}_{\mathrm{m} \theta}^{\prime}=1.05 \mathrm{MPa}$. A comparison of numerical and experimental results for Unit 1 and Unit 2 is reported in Figure 1). This comparison exhibits a good agreement between numerical simulations and experimental results namely in terms of strength and energy capacity parameters. However, an important divergence is observed between numerical and experimental results in terms of the stiffness parameter at the first cycle in both specimens. At first stages of short displacements, this divergence is expected because the experimental curve reflects the MIFS behaviour before the separation of masonry panel from the bounding frames. However, the numerical simulation 
is based on the diagonal strut assumption, which corresponds of the MIFS behaviour after separation of masonry panel. This divergence does not imply an important influence on the design of the MIFS because it corresponds to a very short level of lateral displacement.

The second task for the evaluation of performance indices of the specimens is the determination of the quasi-static responses of the RC bare frames with and without tapered joints corresponding to Unit 1 and Unit 2, respectively. The corresponding RC bare frames should be loaded with the same

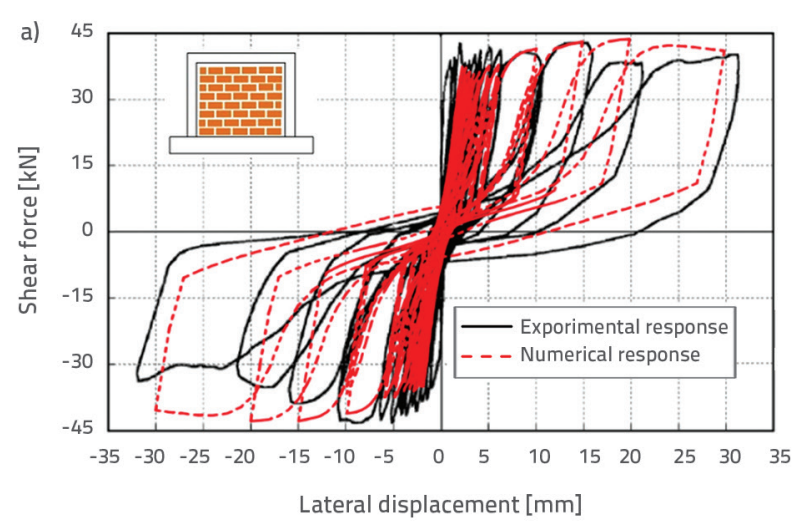

Figure 19. Comparison of numerical simulation with experimental results: a) Unit (01) - Simple MIFS, (b): Unit (02) - MIFS with tapered joints

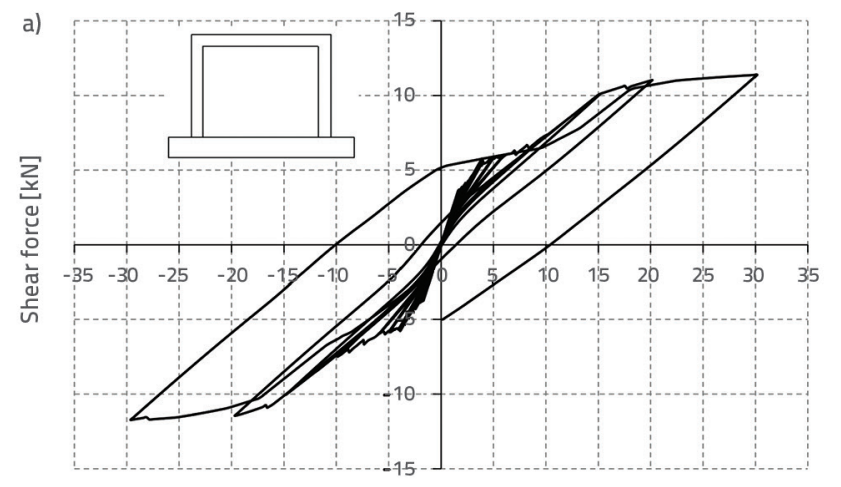

Lateral displacement [mm] lateral displacement actions described in Figure 17. Because of non-existence of experimental tests, the responses of the corresponding RC bare frames are just numerically calculated. Figures 20a and 20b show numerical quasi-static responses of the RC bare frame systems for both Unit 1 and Unit 2.

Based on the superposition principle, the participation of the infill panel masonry specimens in terms of strength can be evaluated according to expression (1). The results are presented graphically in Figure 21. Numerical results indicated in Figure 22a and 22b show that the lateral strength of the MIFS with tapered joint

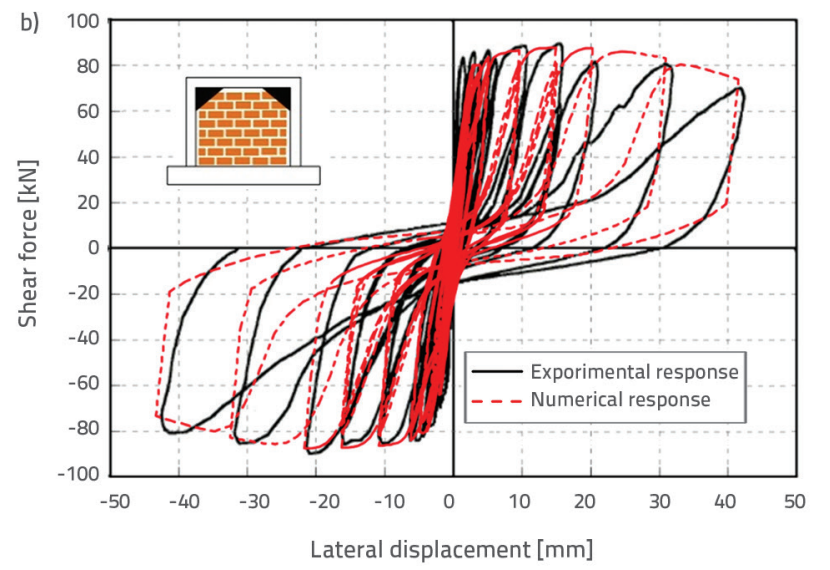

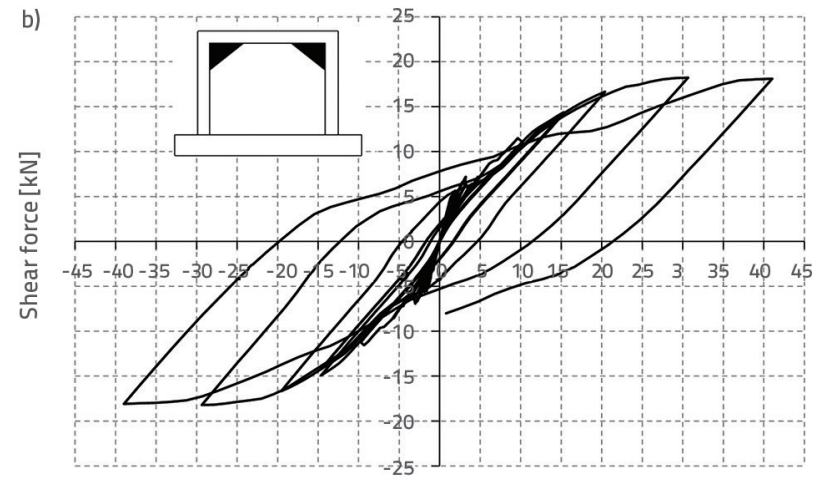

Lateral displacement [mm]

Figure 20. Numerical quasi-cyclic response of RC bare frame system corresponding to: a) Unit 1 - Simple MIFS, b) Unit 2 - MIFS with tapered joints
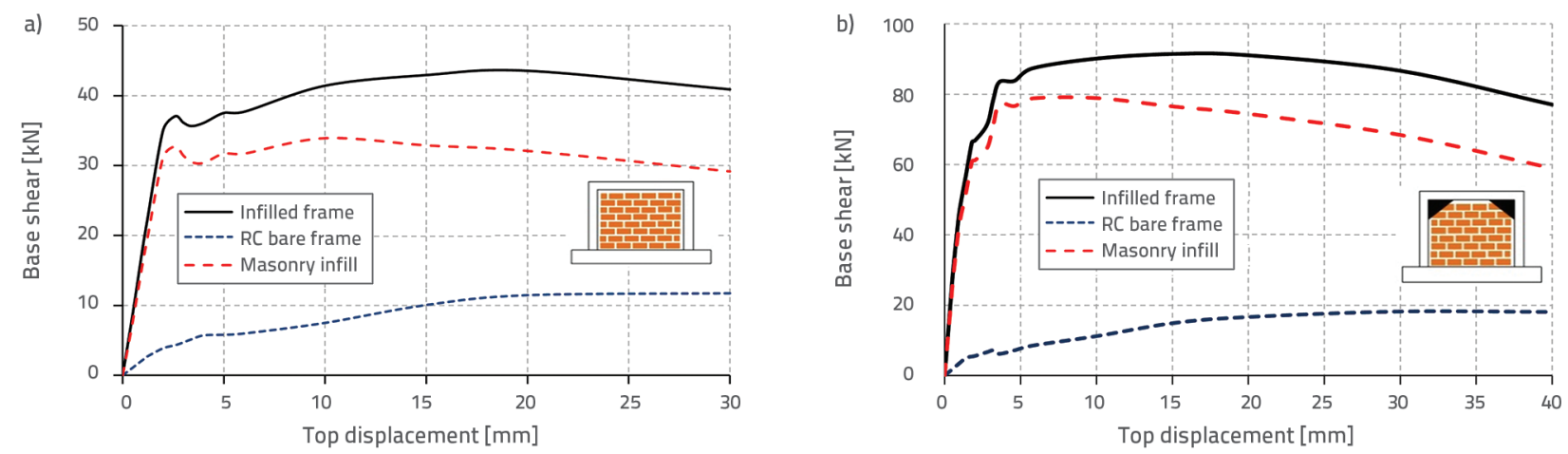

Figure 21. Numerical results: variation of participation in terms of strength of MIFS components: a) Unit 1 - Simple MIFS; b) Unit 2 - MIFS with tapered joints 

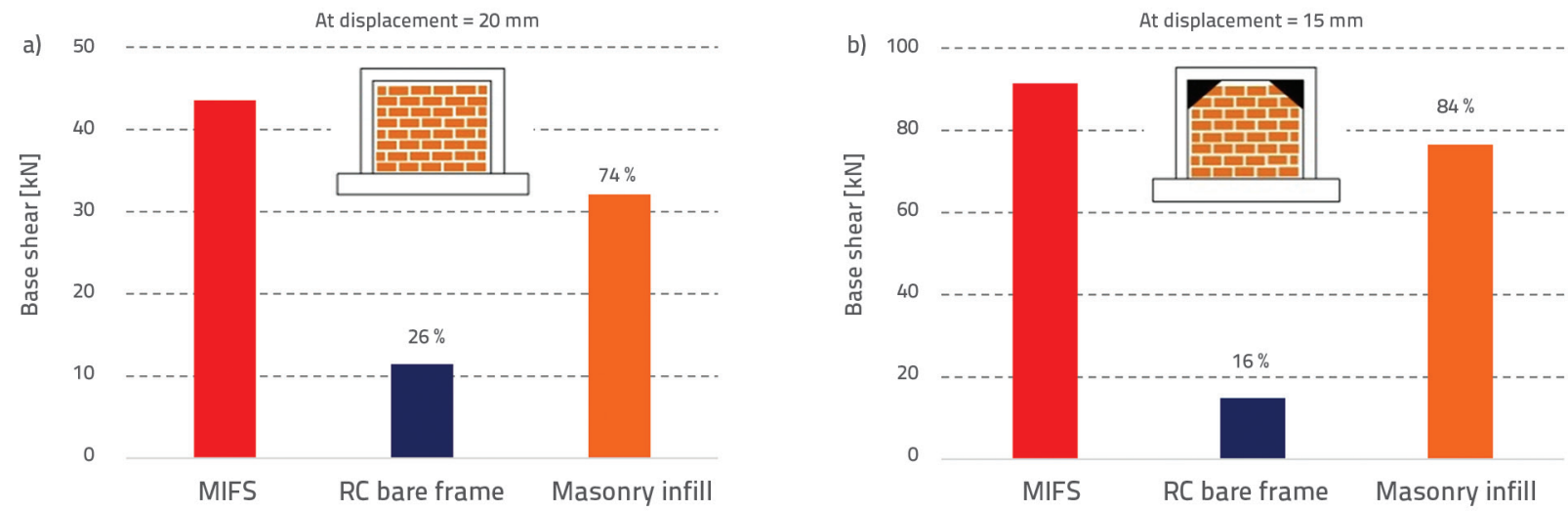

Figure 22. Numerical results: maximum base shear participation of MIFS components: a) Unit 1 - Simple MIFS; b) Unit 2 - MIFS with tapered joints

design is significantly increased. This amelioration corresponds to $110 \%$ of strength of the MIFS with simple design.

Using the formula expressed in (2), the $\mathrm{IP}_{\text {strength }}$ variation of both specimens can be evaluated as a function of displacement at the top. The results are regrouped and presented graphically in Figure 23.

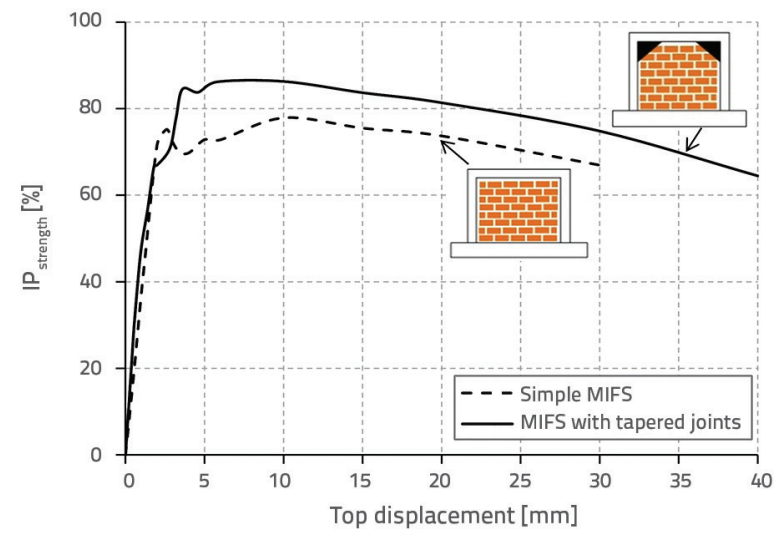

Figure 23. Comparison of Variation of $\mathrm{IP}_{\text {Strength }}$ of: Unit 1 - Simple MIFS and Unit 2 - MIFS with tapered joints

At small displacement, both systems have the same values of $\mathrm{IP}_{\text {Strength }}$ because of monolithic behaviour of the masonry infill panel with the bounding frame (Stage 1). After separation of the infill panel (Stage 2), the maximum value of $\mathrm{PP}_{\text {Strength }}$ for the MIFS with tapered joints reaches $86 \%$ early lat displacement of 5.8 $\mathrm{mm}$ ) compared with $\mathrm{IP}_{\text {strength }}$ of the simple MIFS which reaches
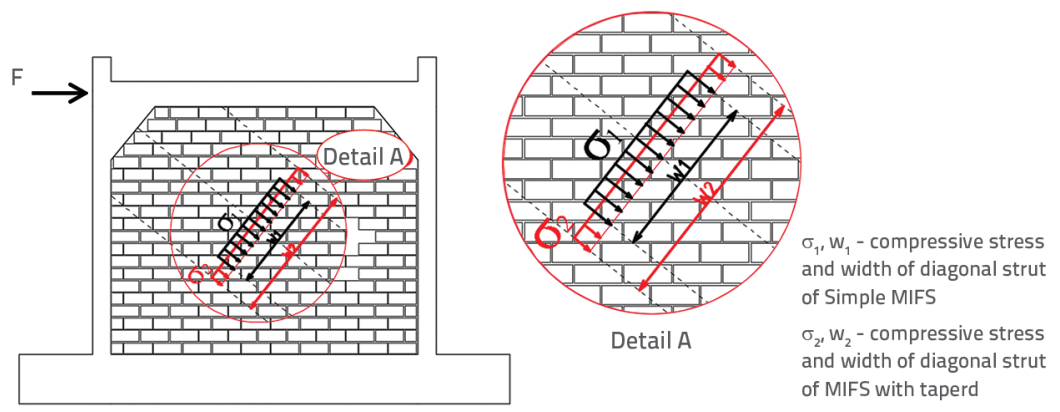

Figure 24. Diagonal compressive stress in masonry infill with tapered joints its maximum value $(78 \%)$ at a displacement level of $10 \mathrm{~mm}$. This indicates that the tapered joint design remarkably improves performance of the infill panel in terms of strength while, on the other hand, the ductility of the MIFS decreases.

The improvement of $\mathrm{IP}_{\text {Strength }}$ of the MIFS with tapered joints is a consequence of an increase in the width of the equivalent compressive strut developed in the infill panel. The increase of the diagonal strut width reduces compressive stress and improves transfer of lateral loads from RC frames to the masonry panel as shown in Figure 24. Table 8 shows that the width of the equivalent diagonal strut of MIFS with tapered joints is about three times that of simple MIFS.

Table 8. Geometric characteristics of the equivalent diagonal strut

\begin{tabular}{|c|c|}
\hline MIFS Stick & $\begin{array}{c}\text { Width of equivalent, Diagonal strut } \\
{[\mathrm{m}]}\end{array}$ \\
\hline Regular MIFS & 0.40 \\
\hline $\begin{array}{c}\text { MIFS with tapered } \\
\text { joints }\end{array}$ & 1.33 \\
\hline
\end{tabular}

Figure (25 a) and b)) shows contribution of the bare frame and the infill panel to the stiffness of simple MIFS and MIFS with tapered frame. In both cases, the masonry infill stiffness curve is close to the MIFS stiffness curve, which reasserts domination of the infill panel effect in the global behaviour of the MIFS. The graphs shown in Figure (25) also indicate that tapered joints increase the stiffness by about three times as compared to the stiffness of simple MIFS. This result is expected because the width of the equivalent diagonal strut at MIFS with tapered joints is also three times greater compared to that of the simple MIFS. (cf. Table 8).

Using expression (5), the variation of $\mathrm{IP}_{\text {Stiffness }}$ of each unit is calculated as a function of displacement at the top and regrouped in the Figure 26.

Figure 26. Comparison of variation of $\mathrm{IP}_{\text {Stiffness }}$ 

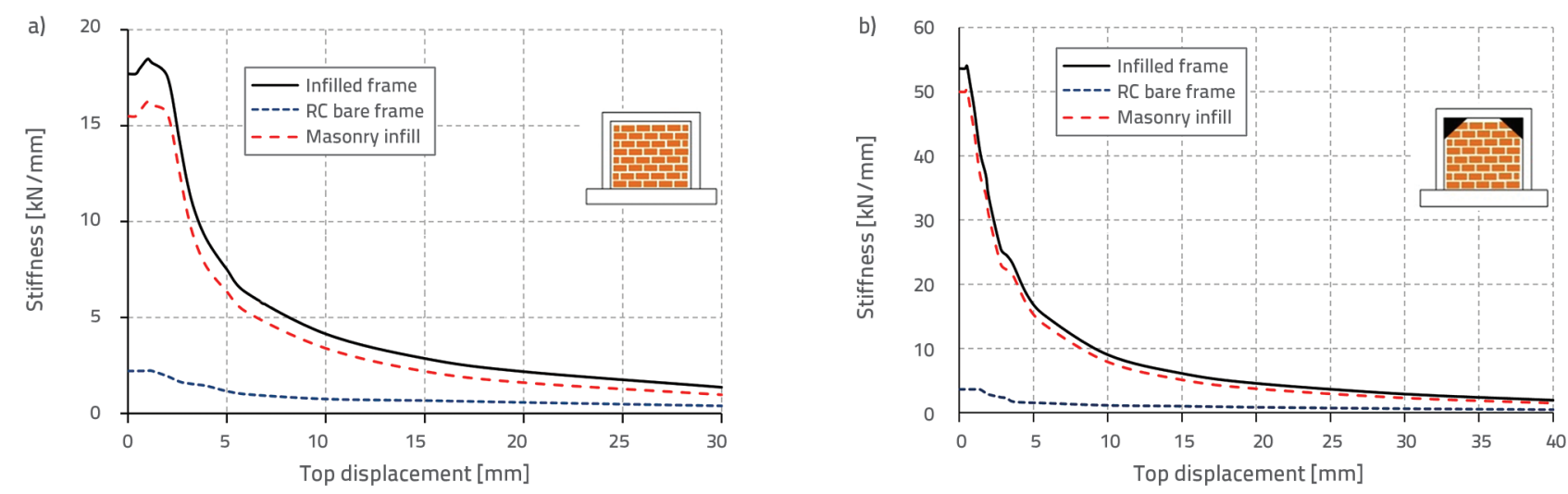

Figure 25. Numerical results: variation of participation in terms of stiffness of each MIFS component: a) Unit 1- Simple MIFS; b) Unit 2 - MIFS with tapered joints

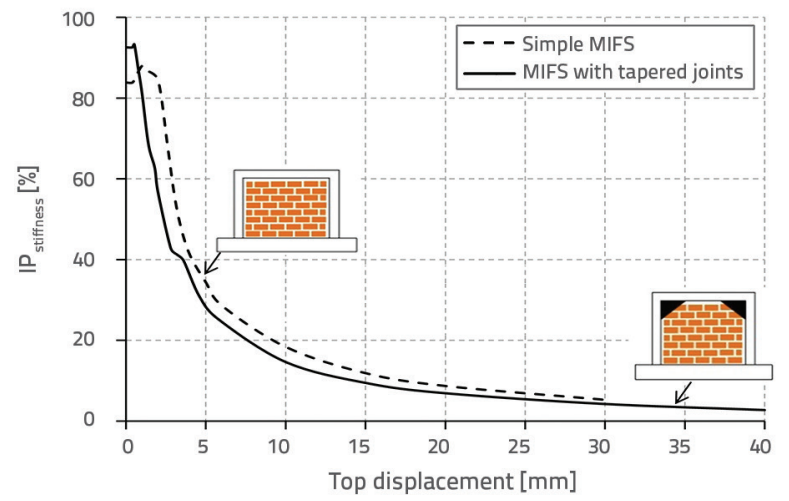

of: Unit 1 - Simple MIFS, and Unit 2 - MIFS with tapered joints

At all displacement levels, the $\mathrm{IP}_{\text {Stiffness }}$ curves of both systems are almost close to each other. So, the $\mathrm{IP}_{\text {Stiffness }}$ values do not change considerably despite a significant increase of stiffness in the presence of tapered joints. In other terms, when using the tapered joint design, the stiffness of the infill panel and that of the MIFS increase with the same ratio. This leads to an important result that the relative dynamic characteristic ratio (mostly the natural frequency of vibration) between the MIFS and the infill masonry panel is practically the same when the tapered joint design is used. Complete description of the lateral behaviour of MIFS is obtained by the estimation of its

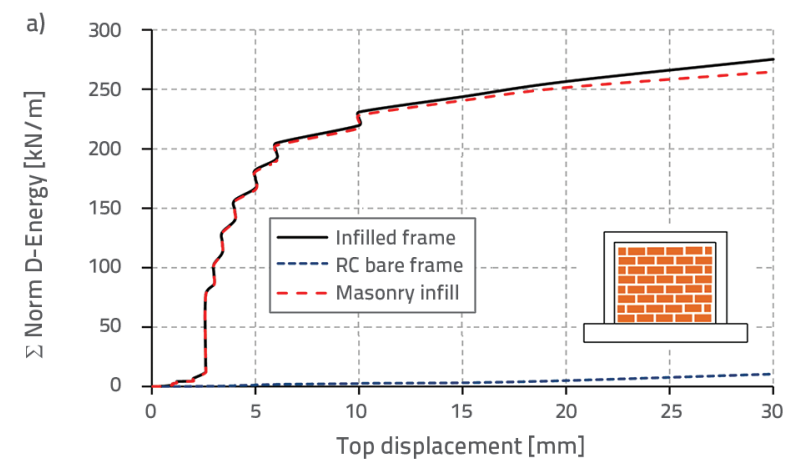

normalized dissipated energy. The normalized dissipated energy is not a decisive parameter for judging performance of MIFS, but it is considered as a complementary element that gives an expressive state of the deterioration of the structure. Based on the above described strength and stiffness results, it is also expected that the capacity of the MIFS with tapered joint to dissipate the energy induced by lateral forces is improved. The variation of the normalized dissipated energy of the specimens is illustrated in Figure (27a and 27b).

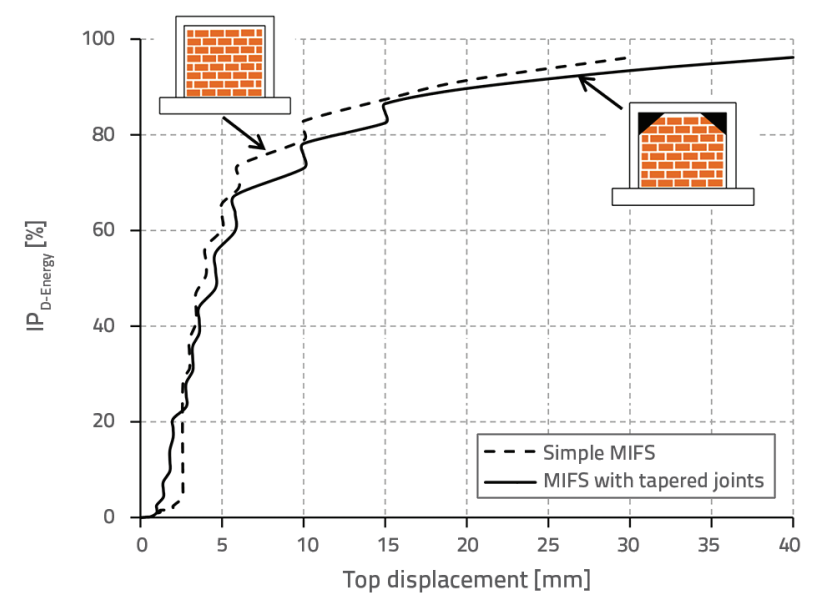

Figure 28. Comparison of variation of $\mathrm{IP}_{\mathrm{D} \text {-Energy }}$ of: Unit 1 - Simple MIFS, and Unit 2 - MIFS with tapered joints

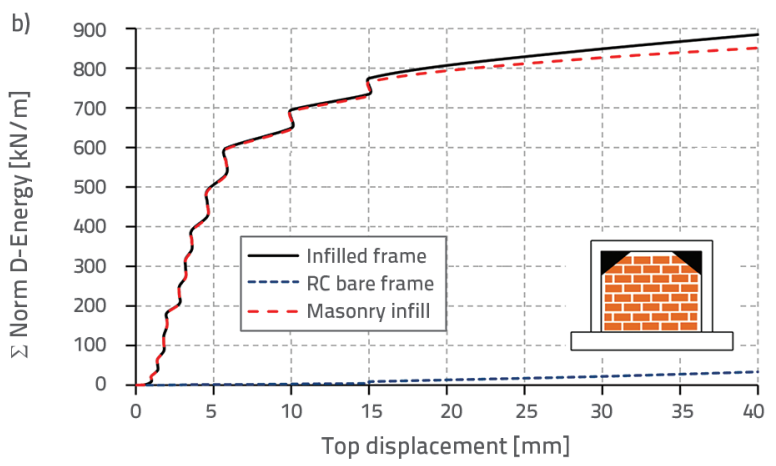

Figure 27. Numerical results: variation of IP participation in terms of stiffness of each component of the MIFS: (a) Unit 1 - Simple MIFS; (b) Unit 2 - MIFS with tapered joints 

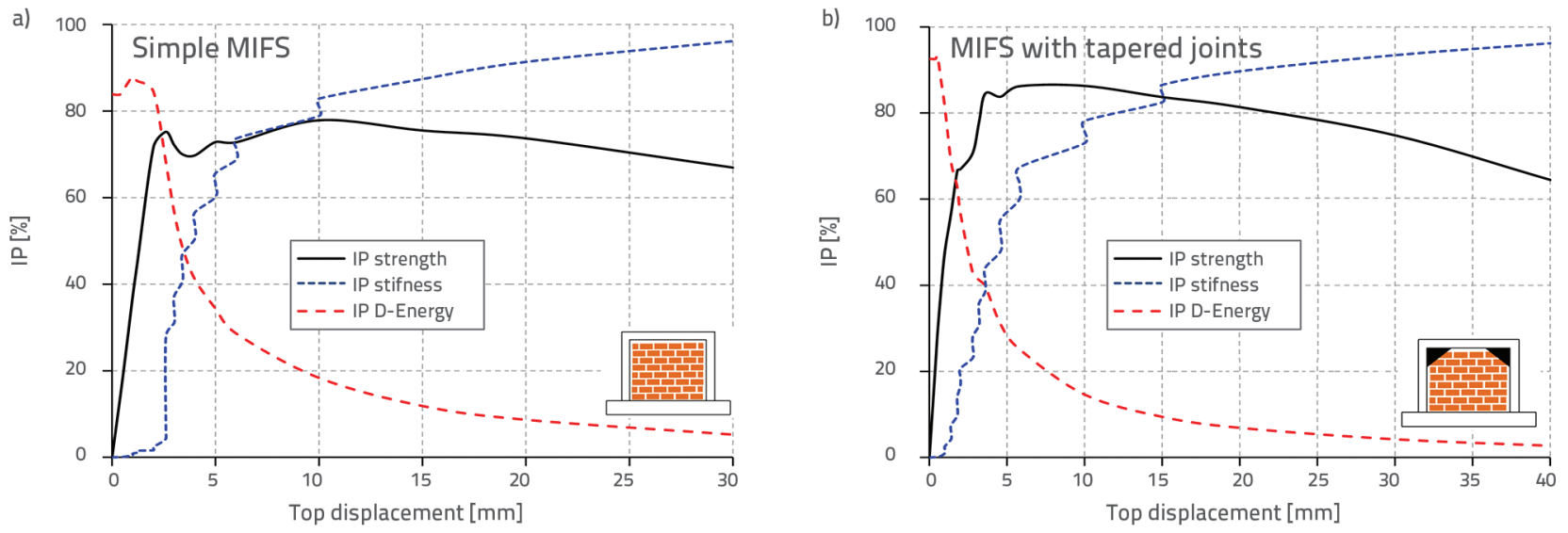

Figure 29. Numerical results: variation of IP of the MIFS: (a) Simple MIFS; (b) MIFS with tapered frames

Table 9. Principal IP results for Unit 1 - Simple MIFS and Unit 2 - MIFS with tapered joints

\begin{tabular}{|c|c|c|}
\hline $\begin{array}{ll}\text { Indices of performance (IP) MIFS } \\
\end{array}$ & Simple MIFS & MIFS with tapered joints \\
\hline Max of $\mathrm{IP}_{\text {Strength }}[\%]$ & 77.88 & 86.20 \\
\hline Target displacement at max of $\mathrm{IP}_{\text {Strength }}[\mathrm{mm}]$ & 10.00 & 5.80 \\
\hline $\mathrm{IP}_{\text {Stiffness }}$ at target displacement [\%] & 18.36 & 25.16 \\
\hline $\mathrm{IP}_{\mathrm{D} \text {-Energy }}$ at target displacement [\%] & 82.88 & 67.35 \\
\hline
\end{tabular}

Table 10. Overview of damage states with corresponding drifts

\begin{tabular}{|c|c|c|c|c|}
\hline Damage state & Slight damage & Moderate damage & Heavy damage & Collapse \\
\hline Drift [\%] & $0.05-0.10$ & $0.20-0.30$ & $0.50-0.75$ & $>1.00$ \\
\hline
\end{tabular}

Both Unit 1 and Unit 2 point to dominant participation of the infill masonry panel in the dissipation of energy. The energy dissipation capacity of the MIFS with tapered joints is about three times that of simple MIFS. The variation of the $\mathrm{IP}_{\mathrm{D} \text {-energy }}$ indicated in Figure 28 shows that the IP $\mathrm{P}_{\text {-energy }}$ of simple MIFS and MIFS with tapered joints are in good agreement mostly at small displacement. This is similar to the above indicated convergence of the $\mathrm{IP}_{\text {Stiffness }}$.

The characterization of performance is summarized in the graphs shown in Figure (29), which express separately the variation of $I P_{\text {Strength' }} I P_{\text {Stiffness }}$ and the $I P_{D \text {-Energy }}$ for each specimen. The IP indicates that the relative strength parameter of simple MIFS and MIFS with tapered joint has improved considerably, compared to other parameters such as stiffness and dissipated energy. This can be explained by the fact that contribution of RC frames is considerable in terms of strength. However, the contribution of masonry infills is dominant in terms of stiffness and dissipated energy.

Principal values of the IP of MIFS with and without tapered joints is recapitulated in Table 9. The values indicated in the above table show that the tapered joint design has improved the contribution of the masonry infill in terms of strength from $77.88 \%$ to $86.20 \%$. These maximum contributions of masonry infill are registered at different lateral displacements for each specimen: $10.00 \mathrm{~mm}$ for simple MIFS versus 5.80 $\mathrm{mm}$ for MIFS with tapered joints. For each of these target displacements, the contribution of the infill panel in terms of stiffness is improved from $18.36 \%$ for simple MIFS to 25.16 $\%$ for MIFS with tapered joints. This indicates that the tapered joints design reduces the degradation of the masonry panel by increasing lateral stiffness and limiting the lateral displacement of MIFS. This is confirmed by the dissipated energy parameter which also indicates a reduction of the masonry infill damage from $82.88 \%$ for simple MIFS to 67.35 $\%$ for MIFS with tapered joints.

\section{Seismic verification of MIFS with $\mathrm{IP}_{\text {Strength }}$}

Based on experimental competences, damage states of MIFS can be expressed by its corresponding drift interval as indicated in [44]. cf. Table 10.

The relationship between variation of $\mathrm{IP}_{\text {strength }}$ and damage state evolution of MIFS is highlighted in Section 3.1 of this work. Figure 30 illustrates the variation of $\mathrm{IP}_{\text {strength }}$ with evolution of damage state of Unit 2 (with tapered joint). The important result inspired by this curve is that slight and moderate damage states are limited by the maximum of $\mathrm{IP}_{\text {strength }}$ values. When reaching the maximum of $\mathrm{P}_{\text {strength }}$, heavy damage to MIFS is initiated and this damage gradually increases until collapse, after a drift of $1.00 \%$. 
So, the index of performance in terms of strength can be used for seismic verification of MIFS by checking that the performance point (which represents the intersection of the capacity's curve with the seismic demand's curve) is situated in the interval between $\mathrm{S}_{\mathrm{d} 1}$ and $\mathrm{S}_{\mathrm{d} 2}$ (cf. Figure 31).

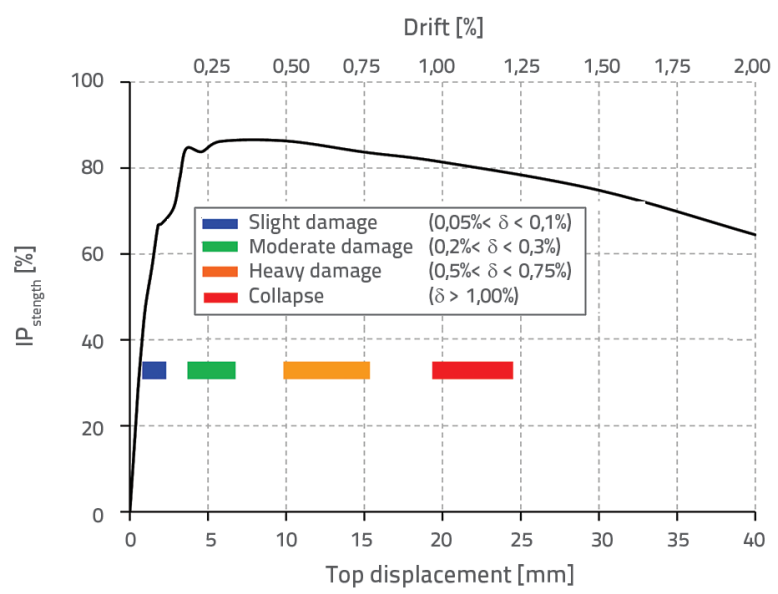

Figure 30. Damage states of MIFS VS IP strength

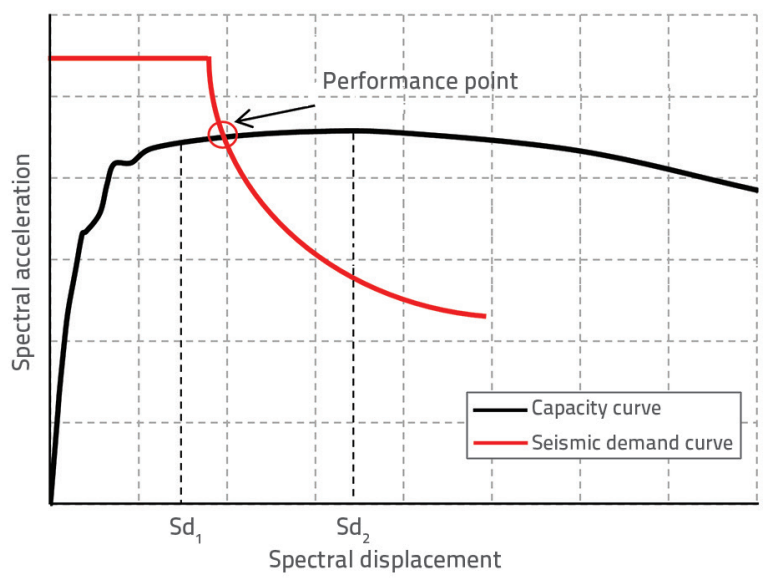

Figure 31. Seismic justification of MIFS with IP ${ }_{\text {Strength }}$

Where:

$S_{d 1}$ : Spectral displacement corresponding of max $I P_{\text {Strength }}$ $\mathrm{S}_{\mathrm{d} 2}$ : Spectral displacement corresponding of max base shear.

The start of degradation of the masonry infill panel constitutes the first limit of moderate damage zone. The lack of strength due to masonry degradation is transferred to $R C$ frame elements. Consequently, despite an decrease in $\mathrm{IP}_{\text {Strength' }}$ the base shear of MIFS increases until reaching its maximum strength capacity at the spectral displacement $\mathrm{S}_{\mathrm{d} 2}$. After this stage, both masonry infill and bonding frames are damaged by an increase in lateral top displacement up to the failure of the MIFS.

\section{Conclusion}

Masonry infilled RC frame structure (MIFS) is a structural typology widely used for construction of low-rise buildings in Algeria and all over the world. When they are built in seismic areas, failure to use masonry infill panels may leads to unfavourable effects and, consequently, to premature failure of the building. The use of numerical simulation to evaluate seismic performance of the masonry infilled RC frame structure still constitutes a real challenge because of the complex behaviour of its components. In this work, a simulation with macro-model of masonry panel processed in a finite element program was used for evaluating performance of masonry infills.

A new method was proposed to evaluate performance of the infill panel in the bounding frames by means of indices of performance. The index of performance (IP) represents the ratio of the masonry panel participation on the overall behaviour of the masonry infilled RC frame structure. The indices of performance are expressed using three parameters: lateral strength, lateral stiffness, and dissipated-energy of a structure. The indices of performance are used to control variation of the panel infill effect as a function of lateral top displacement of the structure. This method constitutes a powerful tool for selecting an optimal design of the masonry infilled RC frame structure that offers better behaviour with regard to seismic loads. This method is not applicable when the MIFS presents a premature failure of its components or when the perfect sliding shear mechanism of panel occurs. In this latter mechanism, plastic hinges are formed at span length, and not at the ends of RC members.

This method is used for studying seismic performance of infilled RC frames with tapered column-beam joints as compared with a similar regular infilled RC frame. The comparison shows that the indices of performance of tapered joints design exhibit significant improvement, especially in terms of strength. The indices of performance highlighted that tapered RC infilled frames (which is a non-famous design) deserve to be employed as competitive variant to avoid premature failure of infilled RC frames.

The indices of performance can also be used for justifying the $\mathrm{RC}$ infilled frames with the seismic codes by the delimitation of the moderate damages zone limited by spectral displacement corresponding of maximum value of the $\mathrm{IP}_{\text {strength }}$ and the maximum base shear of the structure.

In future work, the application of the IP method on MIFS, with different sizes and locations of openings, will be studied with the possibility of using more refined models.

\section{Acknowledgements}

This work was supported by the National Earthquake Engineering Research Centre (CGS) of Algeria. 


\section{REFERENCES}

[1] Smith, S.B.: Behavior of square infilled frames, Journal of the Structural Division ASCE, 92 (1966) 1, pp.381- 404.

[2] Mehrabi, A.B, Shing, P.B.: Finite Element Modeling of MasonryInfilled RC Frames, Journal of Structural enginering,123 (1997) 5, pp. 604-613, https://doi.org/10.1061/(ASCE)07339445(1997)123:5(604)

[3] Al-Chaar, G., Issa, M., Sweeney, S.: Behavior of masonryinfilled non-ductile reinforced concrete frames, Journal of Structural enginering, 128 ( 2002) 8. pp.1055-1063, https://doi. org/10.1061/(ASCE)0733-9445(2002)128:8(1055)

[4] Mosalam, K.H., Hashemi, A.: Shake-table experiment on reinforced concrete structure containing masonry infill wall, Earthquake Engineering and Structural Dynamics, 35(2006) 14, pp. 18271852, https://doi.org/org/10.1002/eqe.612

[5] Schwarz, S., Hanaor, A., Yankelevsky, D.Z.: Experimental Response of Reinforced Concrete Frames with AAC Masonry Infill Walls to In-plane Cyclic Loading, Structures, 3 (2015), pp. 306-319, https:// doi.org/10.1016/j.istruc.2015.06.005

[6] Liauw, T.C., Kwan, K.H.: Plastic Theory of Infilled Frames with finite interface shear strength. Proceedings of the Institution of Civil Engineering. 75 (1983) 4, pp. 707-723, https://doi.org/10.1680/ iicep.1983.1384

[7] Serkan, M.I., Ozgur, O., Sadik, C.G., Serap, K.: Experimental work on seismic behavior of various types of masonry infilled RC frames, Structural Engineering and Mechanics, 44 (2012) 6, pp.763-774, https://doi.org/10.12989/sem.2012.44.6.763

[8] Liborio, C., Fabio, D.T.: Cyclic response of masonry infilled RC frames: Experimental results and simplified modelling, Soil Dynamics and Earthquake Engineering, 65 (2014), pp.224-242, https://doi.org/10.1016/j.soildyn.2014.06.016

[9] Liauw, T.C., Kwan, K.H.: Nonlinear behaviour of non-integral infilled frames, Computers and Structures, 18 (1984) 3, pp.551560, https://doi.org/10.1016/0045-7949(84)90070-1

[10] Crisafulli, F.J., Carr, A.J.: Proposed macro-model for the analysis of infilled frame structures, Bulletin of the New Zealand Society for Earthquake Engineering, 40 (2007) 2, pp. 69-77.

[11] Asteris, P.G.: Finite element micro-modeling of infilled frames, Electronic Journal of Structural Engineering, 8 (2008), pp. 1-11.

[12] Ivo, C., Bartolomeo, P.: A macro-element modelling approach of Infilled Frame Structures, Computers and Structures, 143 ( 2014), pp. 91-107, https://doi.org/10.1016/j.compstruc.2014.07.008

[13] Chrysostomou, C.Z., Asteris, P.G.: On the in-plane properties and capacities of infilled frames, Engineering Structures, 41 (2012), pp.385-402, https://doi.org/10.1016/j.engstruct.2012.03.057

[14] Asteris, P.G. et al.: Mathematical micro modeling of infilled frames: State of the art, Engineering Structures, 56 (2013), pp.19051921, https://doi.org/10.1016/j.engstruct.2013.08.010

[15] ASCE. FEMA: Prestandard and commentary for the seismic rehabilitation of buildings. American Society of Civil Engineers: FEMA-356, Washington, 2000.

[16] Andreaus, U.: Failure criteria for masonry panels under in-plane loading, Journal of structural engineering, 122 (1996) 1, pp. 3746, https://doi.org/10.1061/(ASCE)0733-9445(1996)122:1(37)

[17] Wood, R.H.: Plasticity, composite action and collapse design of unreinforced shear wall panels in frames, Proceedings of the institution of civil engineers, Part 2, 65 (1978) 2, pp. 381-411, https://doi.org/doi.org/10.1680/iicep.1978.2952
[18] Saneinejad, A., Hobbs, B.: Inelastic design of infilled frames, Journal of structural engineering, 121 (1995) 4, pp. 634-650, https://doi.org/10.1061/(ASCE)0733-9445(1995)121:4(634)

[19] Liauw, T.C., Kwan, K.H.: Plastic theory of non-integral infilled frames. Proceedings of the Institution of Civil Engineers, Part 2, 75 (1983) 3, pp. 379-396, https://doi.org/10.1680/iicep.1983.1437

[20] Crisafulli, F.J.: Seismic Behavior of Reinforced Concrete Structures with Masonry Infills, PhD Thesis- Department of Civil EngineeringUniversity of Canterbury, (1997), pp. 219-244.

[21] Mehrabi, A.B., Shing, P.B., Schuller, M.P., Noland, J.L.: Performance of masonry-infilled R/C frames under in-plane lateral loads, Structural Engineering and Structural Mechanics, Research Series, Report CD/SR-94/6, 1994.

[22] Polyakov, S.V.: On the interaction between masonry filler walls and enclosing frame when loaded in the plane of the wall, Translations in Earthquake Engineering, (1960), pp. 36-42.

[23] Holmes, M.: Steel frames with brickwork and concrete infilling, Proceeding of the institution of civil engineering, 19 (1961) 4, pp. 473-478, https://doi.org/10.1680/iicep.1961.11305

[24] Smith, B.S.: Lateral stiffness of infilled frames, Journal of Structural Division, 88 (1962) 6, pp. 183-226.

[25] Paulay, T., Priestley, M.J.N.: Seismic design of reinforced concrete masonry buildings, John Wiley \& Sons, Inc, 1992, https://doi. org/10.1002/9780470172841

[26] Mainstone, R.J.: On the stiffness and strengths of infilled frames, Proceedings of the institution of civil engineers, 8 (1971), pp. 5790.

[27] Smith, B.S., Carter, C.: A method of analysis for infilled frames, Proceedings of the institution of civil engineers, 44 (1969) 1, pp. 31-48, https://doi.org/10.1680/iicep.1969.7290

[28] Tomazevic, M.: Masonry infilled reinforced concrete frames, Earthquake-resistant design of masonry buildings, Imperial College Press, London, pp. 163-178, 1999.

[29] El-Dakhakhni, W.W., Elgaaly, M., Hamid, A.A.: Three-Strut Model for Concrete Masonry-Infilled Steel frames, Journal of structural engineering, 129 (2003) 2, pp. 177-185, https://doi.org/https:// doi.org/10.1061/(ASCE)0733-9445(2003)129:2(177)

[30] Shing, P.B., Stavridis, A.: Analysis of seismic response of masonry infilled RC Frames through Collapse, ACI Structural Journal, 297 (2014) 7.pp.1-20.

[31] Di Trapani, F., Shing, P.B., Cavaleri, L.: Modelling in-plane and outof-plane response of infilled frames through a fiber macro-model, Proceedings of the european opensees association 1st European Conference on OpenSees, Portugal, (2017), pp. 113-116.

[32] Rodrigues, H., Varum, H., Costa, A.: Simplified macro-model for infill masonry panels. Journal of Earthquake Engineering, 14 (2010), pp. 390-416, https://doi.org/10.1080/13632460903086044

[33] Uva, G., Raffaele, D., Porco, F., Fiore, A.: On the role of equivalent strut models in seismic assessment of infilled RC buildings, Engineering Structures, 42 (2012), pp. 83-94, https://doi. org/10.1016/j.engstruct.2012.04.005

[34] Federal Emergency Management Agency (FEMA):: NEHRP guidelines for the seismic rehabilitation of buildings, FEMA-273, Washington, DC, USA. 1997.

[35] Applied Technology Council (ATC):: Seismic evaluation and retrofit of concrete buildings, Volumes 1 and 2, ATC-40, Redwood City, CA, USA, 1996. 
[36] Asteris, P.G. et al.: A macro-modelling approach for the analysis of infilled frame structures considering the effects of openings and vertical loads, Structure and Infrastructure Engineering, 12 (2015) 5, pp. 551-566, https://doi.org/10.1080/15732479.2015.10307 61

[37] Eurocode 8: Design provisions for earthquake resistance of structures, Part 1-3: General rules - specific rules for various materials and elements, ENV 1998-1-3, CEN, Brussels, 1995.

[38] Cavaleri, L., Papia, M.: A new dynamic identification technique: application to the evaluation of the equivalent strut for infilled frames, Engineering structures, 25 (2003), pp. 889-901, https:// doi.org/10.1016/S0141-0296(03)00023-3

[39] Seismosoft [2016]: "SeismoStruct 2016 - A computer program for static and dynamic nonlinear analysis of framed structures," available from http://www.seismosoft.com.

[40] Mann, W., Müller, H.: Failure of Shear-Stressed Masonryan Enlarged Theory, Tests and Application to Shear Walls, Proceedings of the British Ceramic Society, 30 (1982) 1, pp. 223235.
[41] Penava, D., Sarhosis, V., Kožar, I., Guljaš, I.: Contribution of RC columns and masonry wall to the shear resistance of masonry infilled RC frames containing different in size window and door openings, Engineering Structures, 172 (2018), pp. 105-130, https://doi.org/10.1016/j.engstruct.2018.06.007

[42] Kakaletsis, D. Karayannis, C.: Experimental investigation of infilled $\mathrm{r} / \mathrm{c}$ frames with eccentric openings, Structural Engineering and Mechanics, 26(2007), pp. 231-250, https://doi.org/10.12989/ sem.2007.26.3.231

[43] Al Chaar, G.: Non-ductile behavior of reinforced concrete frames with masonry infill panels subjected to in-plane loading. Construction Engineering Research Laboratories. USA. 1998.

[44] Applied Technology Council (ATC). Evaluation of earthquake damaged concrete and masonry wall buildings: basic procedures manual (FEMA 306). California: Redwood City; 1998.

[45] Chen, W.F.: Plasticity in reinforced concrete. J. Ross Publishing, (2007), ISBN-10: 1932159746.

[46] Mohebkhah, A., Tasnimi, A.A.: Distinct element modeling of masonry infilled steel frames with openings. The Open Construction and Building Technology Journal, 6 (2012), pp.42-49. 